University of Nebraska - Lincoln

DigitalCommons@University of Nebraska - Lincoln

2004

Mineralogical maturity in dunefields of North America, Africa and Australia

Daniel R. Muhs

U.S. Geological Survey, dmuhs@usgs.gov

Follow this and additional works at: https://digitalcommons.unl.edu/usgsstaffpub

Part of the Earth Sciences Commons

Muhs, Daniel R., "Mineralogical maturity in dunefields of North America, Africa and Australia" (2004). USGS Staff -- Published Research. 155.

https://digitalcommons.unl.edu/usgsstaffpub/155

This Article is brought to you for free and open access by the US Geological Survey at DigitalCommons@University of Nebraska - Lincoln. It has been accepted for inclusion in USGS Staff -- Published Research by an authorized administrator of DigitalCommons@University of Nebraska - Lincoln. 


\title{
Mineralogical maturity in dunefields of North America, Africa and Australia
}

\author{
Daniel R. Muhs* \\ U.S. Geological Survey, MS 980, Box 25046, Federal Center, Denver, CO 80225, USA
}

Accepted 16 July 2003

\begin{abstract}
Studies of dunefields in central and western North America show that mineralogical maturity can provide new insights into the origin and evolution of aeolian sand bodies. Many of the world's great sand seas in Africa, Asia and Australia are quartzdominated and thus can be considered to be mineralogically mature. The Algodones (California) and Parker (Arizona) dunes in the southwestern United States are also mature, but have inherited a high degree of mineralogical maturity from quartz-rich sedimentary rocks drained by the Colorado River. In Libya, sediments of the Zallaf sand sea, which are almost pure quartz, may have originated in a similar fashion. The Fort Morgan (Colorado) and Casper (Wyoming) dunefields in the central Great Plains of North America, and the Namib sand sea of southern Africa have an intermediate degree of mineralogical maturity because their sources are large rivers that drained both unweathered plutonic and metamorphic rocks and mature sedimentary rocks. Mojave Desert dunefields in the southwestern United States are quite immature because they are in basins adjacent to plutonic rocks that were their sources. Other dunefields in the Great Plains of North America (those in Nebraska and Texas) are more mature than any possible source sediments and therefore reflect mineralogical evolution over time. Such changes in composition can occur because of either of two opposing long-term states of the dunefield. In one state, dunes are stable for long periods of time and chemical weathering depletes feldspars and other weatherable minerals in the sediment body. In the other state, which is most likely for the Great Plains, abrasion and ballistic impacts deplete the carbonate minerals and feldspars because the dunes are active for longer periods than they are stable.
\end{abstract}

(C) 2003 Elsevier B.V. All rights reserved.

Keywords: Aeolian processes; Desert geomorphology; Geochemistry; Mineralogy; Sand dunes; Sediment composition; Sediment sources; Quaternary

\section{Introduction}

In contrast to many Quaternary sediments, such as alluvium, colluvium, till and beach deposits, aeolian sediments often have a relatively homogenous and simple mineralogy. In the broadest sense, aeolian

* Tel.: +1-303-236-7919; fax: +1-303-236-5349.

E-mail address: dmuhs@usgs.gov (D.R. Muhs). sands can be classified mineralogically into four groups: (1) carbonate-rich sands, sometimes cemented into aeolianite, derived from modern or ancient carbonate rocks or sediments; (2) gypsum-rich sands; (3) volcaniclastic sands, found adjacent to large outcrops of basalt, that have a mafic mineral composition; and (4) quartzo-feldspathic (or siliciclastic) sands, derived from plutonic and metamorphic rocks. Carbonate-rich dunes occur on many subtropical and tropical coast- 
lines (Gardner, 1983; Brooke, 2001; Abegg et al., 2001), but are of limited geographic extent. Gypsum dunes are found in North America, Saudi Arabia, Australia and elsewhere (McKee, 1966; Fryberger et al., 1983; Chen et al., 1991), but are of even more limited extent than carbonate-rich dunes. Mafic-mineral-rich dunes also have a limited geographic distribution on Earth, although they are probably dominant on Mars (Edgett and Lancaster, 1993). Quartzo-feldspathic aeolian sands are the most extensive duneforming sediments worldwide and this paper focuses on these widespread deposits.

Despite the fact that they are derived ultimately from upper crustal rocks of average (granodiorite) composition, many dunefields are characterized as being dominated by quartz (Cooke and Warren, 1973; McKee, 1983; Pye and Tsoar, 1990; Lancaster, 1995; Livingstone and Warren, 1996). Linear dunes in both the Kalahari and Namib Deserts of southern Africa are 90\% quartz (Lewis, 1936; Barnard, 1973; see also Lancaster, 1989 for other mineralogical data). In the Jafurah sand sea of Saudi Arabia, dunes are $90-99 \%$ quartz (Anton, 1983). Quartz contents of linear dunes in the northern parts of the Great Sandy Desert (Canning Basin) area of northwestern Australia are generally $95 \%$ and as high as $99 \%$ (Goudie et al., 1993). In North America, some dunes of the Moenkopi Plateau in northeastern Arizona are up to $100 \%$ quartz (Billingsley, 1987) and sand in the Monahans dunefield of southwestern Texas is $98-99 \%$ quartz (Machenberg, 1984).

Mineralogical maturity, as the term is used in this paper, can be defined as a compositional state of a clastic sedimentary body wherein there is a dominance of quartz and an absence or minority of lessresistant particles such as feldspars, detrital carbonates or lithic fragments (Blatt et al., 1972; Pettijohn et al., 1972). Sandstones that meet this definition are classified as quartz arenites or orthoquartzites if they are at least 95\% quartz (Pettijohn et al., 1972). Thus, aeolian sediments in many of the world's great sand seas may be classified as quartz arenites, a state of maturity that Pettijohn et al. (1972, p. 216) describe as “...the most texturally and compositionally mature of all sands. Some approach the theoretical end point in sand evolution".

Mineralogical maturity, as a key to sediment provenance, transport history, and weathering history has been used extensively by sedimentary petrologists and sedimentologists (Schwab, 1975; Potter, 1978, 1994;

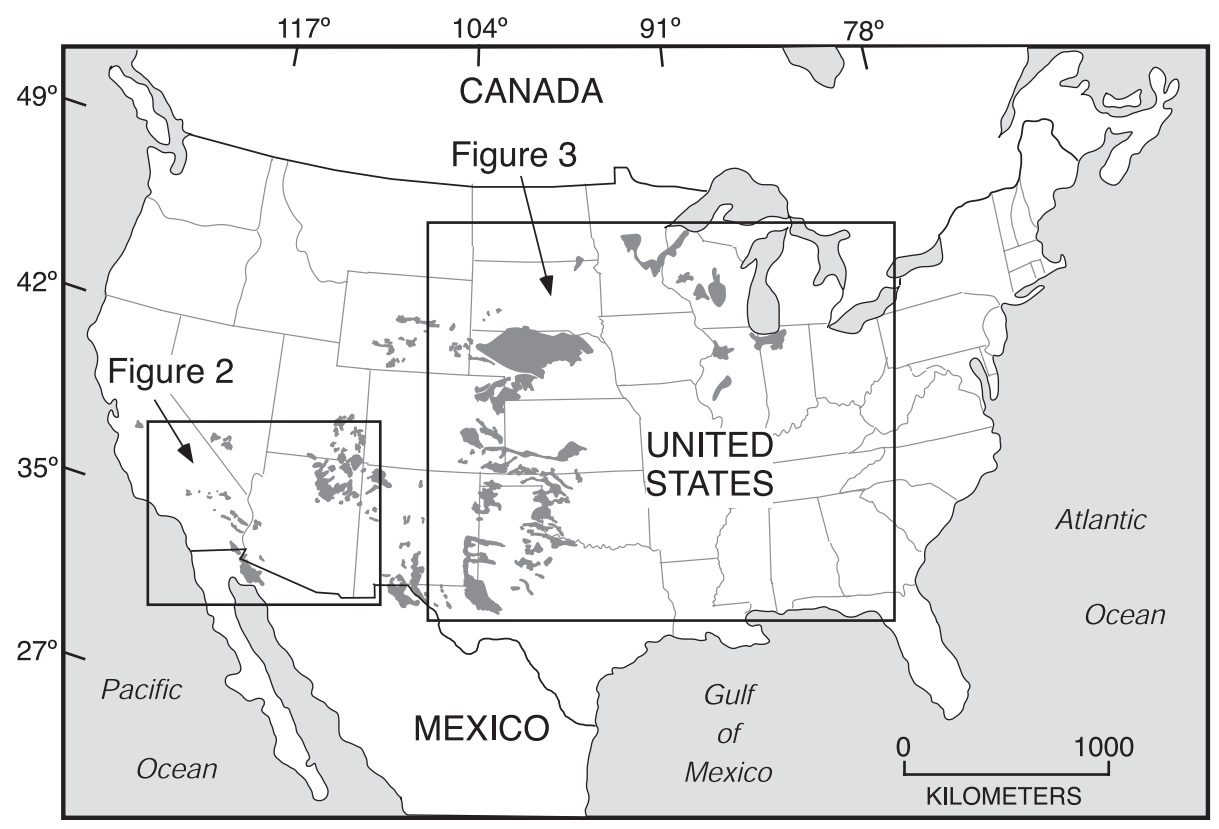

Fig. 1. Map showing the distribution of aeolian sand (areas in dark grey) in the central and western United States. Aeolian sand distribution from Thorp and Smith (1952), Muhs and Holliday (1995) and Muhs and Zárate (2001). 
Potter et al., 2001; Suttner et al., 1981; Franzinelli and Potter, 1983; Suttner and Dutta, 1986; Johnsson et al., 1988; Nesbitt and Young, 1996; Nesbitt et al., 1996, 1997). However, aeolian geomorphologists have not generally exploited the composition and degree of mineralogical maturity of dune sands in studies of sediment transport and aeolian landscape evolution. Studies conducted in the Great Plains region of North America indicate that there are significant differences in the degree of mineralogical maturity from dunefield to dunefield, suggesting different source sediments, transport history, or weathering history (Muhs and Holliday, 2001; Muhs et al., 1997a; Arbogast and Muhs, 2000). In this paper, the potential for using mineralogical maturity as a key to dunefield origins and history is explored, using examples from the Great Plains and southwestern deserts of the United States (Figs. 1-3), the Kallaf sand sea (Sahra Awbari) of Libya, the Namib sand sea of southwestern Africa, and the Great Sandy Desert of Australia.

\section{Methods}

In this study, mineralogy was determined semiquantitatively by X-ray diffractometry and quantitatively by the use of geochemical proxies for bulk aeolian sand samples. Relative abundances of quartz

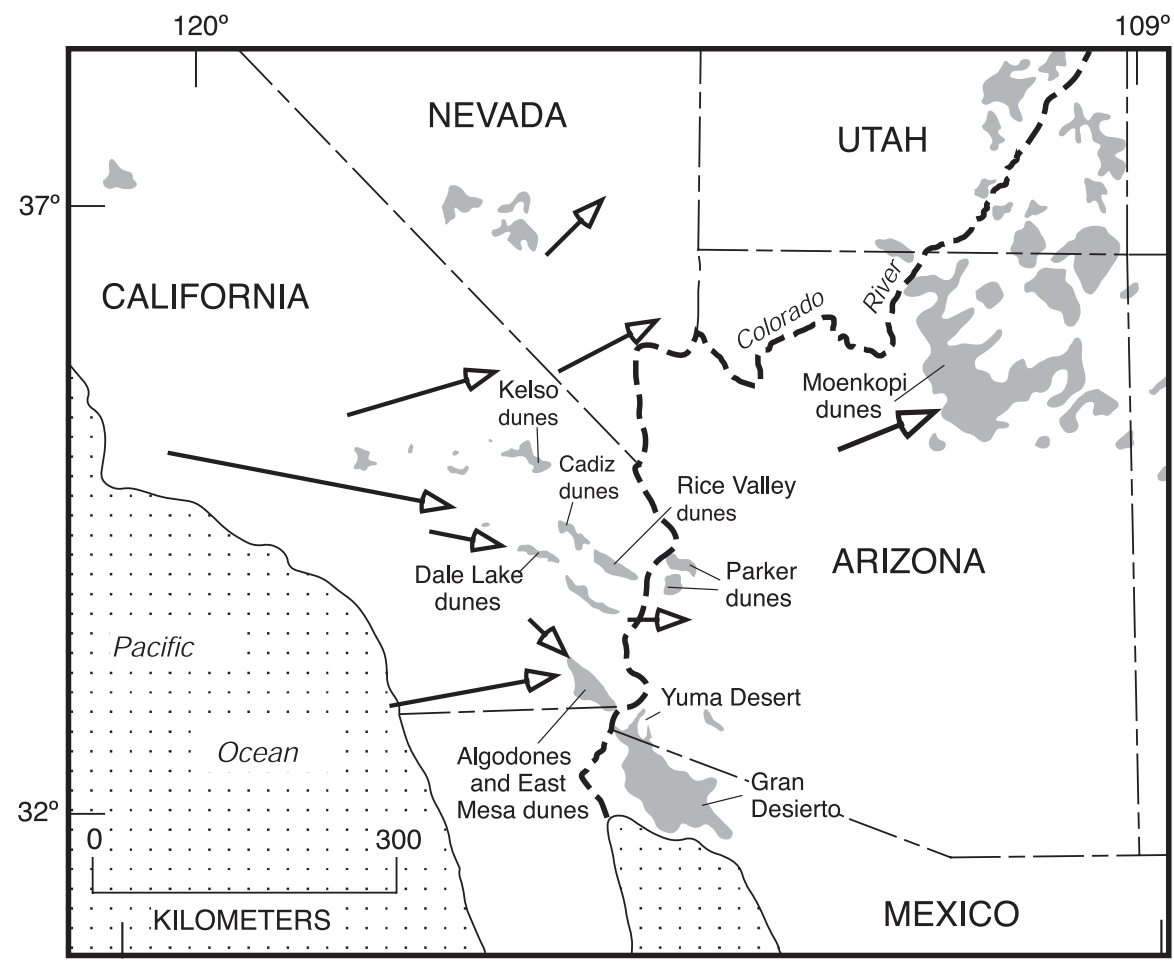

Eolian sand

Resultant annual drift potential of modern winds (vector "units")

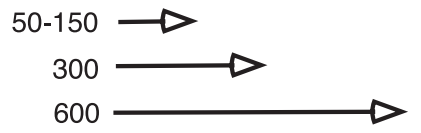

Fig. 2. Map showing the distribution of aeolian sand (grey areas) in the southwestern United States (from compilation by Muhs and Zárate, 2001), location of the lower Colorado River (dashed line in bold), and sand roses (modern resultant drift directions and magnitudes), using the method of Fryberger and Dean (1979). Sand roses generated by the author. 


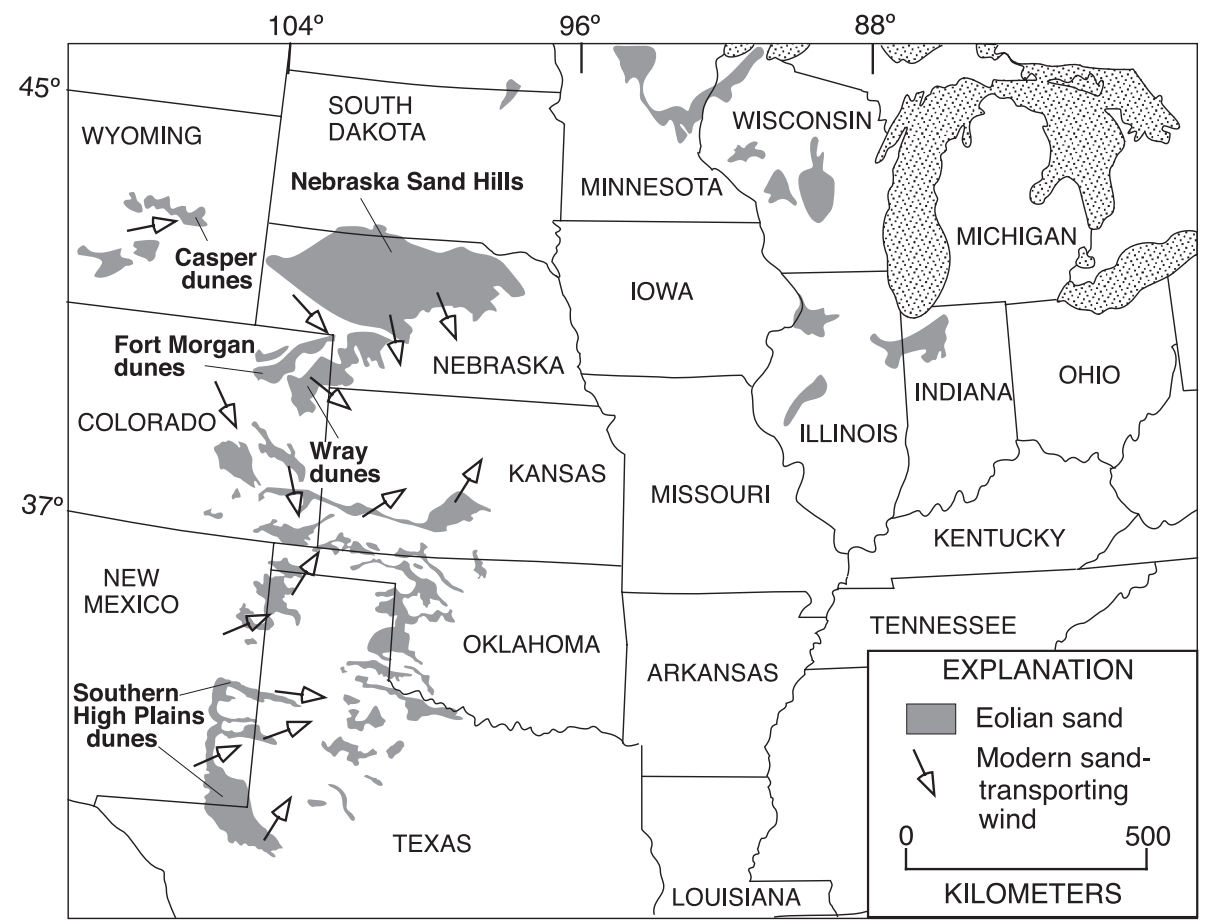

Fig. 3. Map showing the distribution of aeolian sand (grey areas) in the central United States and modern sand roses. Aeolian sand distribution east of longitude $96^{\circ}$ compiled by Thorp and Smith (1952); all other areas compiled by Muhs and Holliday (1995). Sand roses generated by the author.

$\left(20.8^{\circ} 2 \theta\right)$, K-feldspar $\left(27.4^{\circ} 2 \theta\right)$, and plagioclase $\left(27.8^{\circ} 2 \theta\right)$ were determined by measuring X-ray diffractogram peak heights on either bulk aeolian sands or pretreated (as described below) source sediments. Major element concentrations were determined using wavelength-dispersive X-ray fluorescence. This method has typical detection limits of $0.01 \%$ for major elements. Precision by this method is excellent, with duplicate analyses having average agreement within $0.1 \%\left(\mathrm{SiO}_{2}\right), 0.02 \%\left(\mathrm{Al}_{2} \mathrm{O}_{3}\right), 0.01 \%\left(\mathrm{~K}_{2} \mathrm{O}\right)$ and better than $0.01 \%\left(\mathrm{Na}_{2} \mathrm{O}\right)$. In the discussions of individual dunefields that follow, the degree of mineralogical maturity is portrayed as a plot of $\mathrm{SiO}_{2}$ (quartz) vs. $\mathrm{K}_{2} \mathrm{O}$ (K-feldspar) $+\mathrm{Na}_{2} \mathrm{O}$ (plagioclase) $+\mathrm{Al}_{2} \mathrm{O}_{3}$ (all feldspars), following the approach used by Suttner and Dutta (1986). Typically, these two variables are inversely correlated in an expected linear fashion: higher-quartz sediments have higher $\mathrm{SiO}_{2}$ and lower feldspar $\left(\mathrm{K}_{2} \mathrm{O}+\mathrm{Na}_{2} \mathrm{O}+\mathrm{Al}_{2} \mathrm{O}_{3}\right)$ contents.

Samples of possible source sediments for the various dunefields include modern alluvium, older (early
Pleistocene and Pliocene) aeolian sheet sands, and poorly consolidated bedrock. These samples were pretreated as follows: (1) gentle mechanical disaggregation, (2) dry-sieving to remove gravels, (3) removal of carbonate cement, where present, with an Na-acetate buffer $(\mathrm{pH}=5)$, (4) dispersion with Na-pyrophosphate and ultrasonication, (4) removal of $<53-\mu \mathrm{m}$ silts and clays by wet-sieving, (5) removal of $>500-\mu \mathrm{m}$ (California and Arizona source sediments), $>425-\mu \mathrm{m}$ (Colorado, New Mexico and Texas source sediments) or $>250-\mu \mathrm{m}$ (Nebraska source sediments) particles by dry-sieving, and (6) grinding of the remaining sands. The sand-size breaks used for the source sediments $(500,425$ or $250 \mu \mathrm{m})$ were chosen on the basis of the modal particle sizes of the various dunefields.

One exception to bulk aeolian sediment analysis was a suite of samples from E.D. McKee's collections made in the Great Sandy Desert of northwestern Australia. As pointed out by Goudie et al. (1993), dune sands of the Great Sandy Desert (Canning Basin region) have a distinct, red, clay-silt-Fe-oxyhydroxide coating on 
most grains. This coating was removed, as much as possible, after treatment with $\mathrm{H}_{2} \mathrm{O}_{2}$ (to destroy organic matter) and repeated ultrasonic baths in an Na-pyrophosphate dispersant, followed by wet-sieving (53 $\mu \mathrm{m})$. After multiple iterations of this procedure, most grain coatings were removed, such that the original sand-grain mineralogy could be determined.

\section{Hypothetical causes of mineralogical maturity in dunefields}

\subsection{Inheritance from a quartz-rich source sediment}

Previous studies suggest that there are at least five possible mechanisms whereby quartz enrichment can take place in dunefields. The first of these is the least complicated, and has been used to explain the origin of quartz arenites (Pettijohn et al., 1972, p. 224). This process is simply inheritance from an already-mature source sediment, with no intermediate-stage chemical weathering or mechanical loss of feldspar or rock fragments. An example of this would be derivation of dune sands, either directly or indirectly, from a quartzrich sandstone bedrock source. The problem with this explanation is that there are many mineralogically mature dunefields in regions where a quartz-dominated source sediment is absent (see examples below). Furthermore, this explanation begs the question of how the source sediment itself became mature.

\subsection{Chemical weathering of feldspars in the source sediment region}

A second explanation for mineralogical maturity is that chemical weathering reduces feldspar and lithic particle abundances in soils (Basu, 1976; Suttner et al., 1981; Johnsson et al., 1988; Nesbitt et al., 1996, 1997). Later erosion of these feldspar-depleted soils into the drainage system results in a quartz-dominated alluvium that serves as the source of aeolian sediment. This is also essentially a process of inheritance of quartz-rich sediment, but does not require a quartzdominated bedrock in the source region. Many sedimentary petrologists have appealed to this explanation for the origin of quartz arenites. It is usually assumed that sandstones originate by this mechanism after multiple cycles of weathering, erosion and transpor- tation, but first-cycle quartz arenites have also been reported (Johnsson et al., 1988). The main problem with this mechanism for the origin of Quaternary sands is that many dunefields occur in desert regions, where potential source sediments experience little or no chemical weathering. Another problem is that, because many dunefields may be no older than middle or late Quaternary, it is questionable how many cycles of chemical weathering source sediments may have experienced, even in humid regions.

\subsection{Fluvial size reduction of feldspars}

A third explanation for mineralogically mature dunefields is size reduction of feldspars via abrasion and impacts during fluvial transport, prior to aeolian transport. In this process, sandy point bars in downstream reaches of rivers are quartz-rich, because siltsized feldspars or lithic fragments remain in suspension and are carried downstream from the bars. The mechanism requires neither a mineralogically mature bedrock source nor intense chemical weathering in the source region. Pittman (1969) demonstrated loss of twinned feldspar derived from granitic sources along the Merced River in California in less than $80 \mathrm{~km}$ of transport. Cameron and Blatt (1971) reported loss of schist particles downstream from the Black Hills in South Dakota. However, a greater number of studies have shown that in most rivers, there is little change in the amount of quartz relative to feldspar or lithic fragments as a function of distance downstream (Hayes, 1962; Breyer and Bart, 1978; Nesbitt and Young, 1996; Potter et al., 2001). In some regions, increases in quartz abundance downstream are found, but are explained by contributions from tributaries that drain quartz-rich terrains (Franzinelli and Potter, 1983).

\subsection{Loss of feldspars from chemical weathering within a dunefield during long periods of dune stability}

During a long period of dune stability, under favorable climatic conditions (e.g., high rainfall and abundant organic-acid-generating vegetation), feldspars in aeolian sands could be depleted by chemical weathering, leaving a quartz-enriched soil profile in the upper part of the aeolian sediment column. Reactivation of aeolian sand under different climatic con- 
ditions (e.g., greater aridity) could release these quartz-enriched sediments to transport by wind. Repeated cycles of this kind could, in principle, result in a quartz-enriched dunefield. The mechanism requires that regions affected by this process have experienced long periods of dune stability with significant chemical weathering, separated by relatively short periods of dune activity.

\subsection{Loss of feldspars by abrasion or ballistic impacts within a dunefield during long periods of dune activity}

In direct contrast to the mechanism just described, quartz enrichment could also result from extended periods of activity within a dunefield. One hypothesized process for quartz enrichment is aeolian abrasion of less-resistant minerals such as feldspars. It has been documented or asserted that wind abrasion can reduce sand-sized non-quartz particles to silt sizes, with the result that silts are deflated away, leaving a quartz-sandrich residue (Marsland and Woodruff, 1937; Kuenen, 1960; Greeley and Iversen, 1985). Many investigators have reported or assumed that sand grains in dunefields are well-rounded, and grain roundness is usually interpreted to mean that wind abrasion has been an important process. In contrast, Goudie and Watson (1981), in a survey of aeolian sand grains from around the world, reported that most quartz and feldspar grains in desert dunefields are only subrounded to subangular. Thus, it seems likely that wind abrasion of sand-sized feldspars to silt sizes may not be as important a process as previously thought. Nevertheless, abrasion of soft minerals, such as gypsum, calcite and dolomite, is likely an important process in dunefields, based on both experimental studies (Marsland and Woodruff, 1937; Kuenen, 1960) and field studies (Muhs et al., 1997b; Arbogast and Muhs, 2000).

When source sediments have the requisite composition, aeolian transport can result in fragmentation of sand-sized aggregates of smaller particles. For example, Coudé-Gaussen et al. (1983), working in Mali, showed that aeolian sands become enriched in quartz downwind. The quartz enrichment is due to the breakup, during aeolian transport, of sand-sized aggregates of clay minerals that are derived from lacustrine source sediments. These workers showed quartz concentrations increasing from $35 \%$ or less to $\sim 67 \%$ in as short a downwind distance as $15 \mathrm{~km}$.
Impacts during aeolian transport can break up particles that are much harder than clay aggregates. Dutta et al. (1993) have shown, on the basis of both theoretical calculations and laboratory experiments, that ballistic impacts under strong $\left(>10 \mathrm{~m} \mathrm{~s}^{-1}\right)$ winds can result in the mechanical breakdown of sand-sized $\mathrm{K}$-feldspar to silt sizes. Silt-sized K-feldspars are then removed from a dunefield by suspension in wind, leaving a sand-sized, quartz-rich residue. Although the amount of reduction of sand-sized feldspars to silt sizes by aeolian abrasion may have been overestimated in the past, the importance of size reduction of feldspars by ballistic impacts may have been underestimated or even ignored.

These five mechanisms all have very different implications for the origin of dunefields. The first three processes are essentially all mechanisms of quartz enrichment by inheritance, whether from quartz-rich bedrock, fluvial processes, chemical weathering processes or some combination of the three. Hence, identification of quartz enrichment in a dunefield by inheritance says little about dunefield history. The last two mechanisms, however, are processes that take place within a dunefield itself and therefore can yield important clues about aeolian history and landscape evolution. Furthermore, the two mechanisms have opposing implications for the long-term history of a dunefield: one implies long periods of aeolian sand stability whereas the other implies long periods of aeolian sand activity.

\section{Dunefields in the central and western United States with different degrees of mineralogical maturity}

\subsection{Inheritance from quartz-rich or feldspar-rich source sediments in a region of minimal chemical weathering: the Sonoran and Mojave Deserts}

In desert regions of the southwestern United States and northwestern Mexico, there are many small dunefields (Fig. 2). In the Sonoran Desert, Muhs et al. (1995) and Winspear and Pye (1995) showed that the Colorado River is most likely the source of sand for the Algodones dunes in southeastern California. Studies by Zimbelman and Williams (2002), Pease and Tchakerian (2003) and Muhs et al. (2003) have now demonstrated 
that the Parker dunes of western Arizona are also likely derived from sediments of the Colorado River.

Based on the results of all investigators who have studied them (see review in Muhs et al., 1995), the Algodones and Parker dunes are relatively mature mineralogically. In the Algodones dunes, $\mathrm{SiO}_{2}$ contents are $83-88 \%$ and the Parker dunes are $87-90 \% \mathrm{SiO}_{2}$ (Fig. 4). In both dunefields, $\left(\mathrm{K}_{2} \mathrm{O}+\mathrm{Na}_{2} \mathrm{O}+\mathrm{Al}_{2} \mathrm{O}_{3}\right)$ contents are only $7-8 \%$. The chemistry and quartz contents of these dunes are similar to many subarkoses. Sand-sized sediments of the Colorado River are also fairly mature, although somewhat more variable than the dune sands, and range from $78 \%$ to $85 \% \mathrm{SiO}_{2}$. Thus, the mineralogical maturity of the Algodones and Parker dunes is due, at least in part, to inheritance from the already-mature sands of the lower Colorado River. The lower Colorado River, in turn, probably owes its mature sediment composition to inheritance from quartz-rich rocks that crop out upstream of the Mojave and Sonoran Deserts, in northern Arizona, southeastern Utah and western Colorado. This upstream region has extensive outcrops of the quartz-rich Coconino, Navajo and Kayenta Sandstones (McKee, 1979). Note, however, that both the Algodones and Parker dunes are somewhat more mature, on average, than Colorado

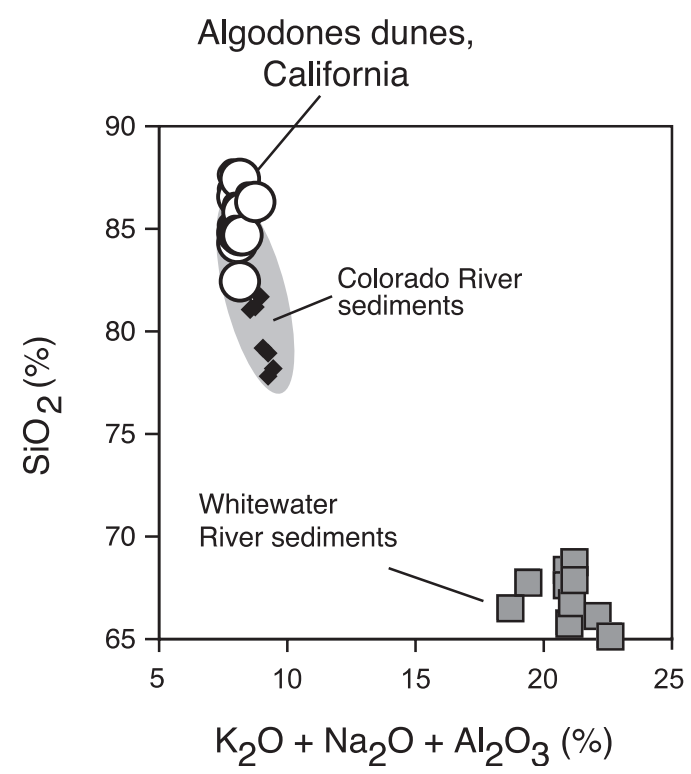

River sediments (Fig. 4). This additional quartz enrichment may be due to processes within the dunefields themselves, a theme discussed later.

In contrast, aeolian sand in the Mojave Desert of California, such as that in the Rice Valley dunefield, has a composition similar to arkose. $\mathrm{SiO}_{2}$ contents are $66-78 \%$ and $\left(\mathrm{K}_{2} \mathrm{O}+\mathrm{Na}_{2} \mathrm{O}+\mathrm{Al}_{2} \mathrm{O}_{3}\right)$ contents are $16-$ $22 \%$ (Fig. 4). Dunes in this area are derived from local alluvium, in turn derived from granitic intrusions (Muhs et al., 2003). These sands have experienced little or no chemical weathering in this arid region, have undergone only short distances of transport, and are far less mature than the Parker and Algodones dunes (Fig. 4). Other Mojave Desert dunes likely have a similar origin, but require further study.

\subsection{Intermediate mineralogical maturity in young} dunefields derived from alluvium of mixed bedrock sources: Great Plains of Colorado and Wyoming

In some dunefields, an intermediate degree of mineralogical maturity may be inherited from fluvial sediments that have received inputs from a variety of rock types, which in turn have varying degrees of mineralogical maturity. Two dunefields in the central

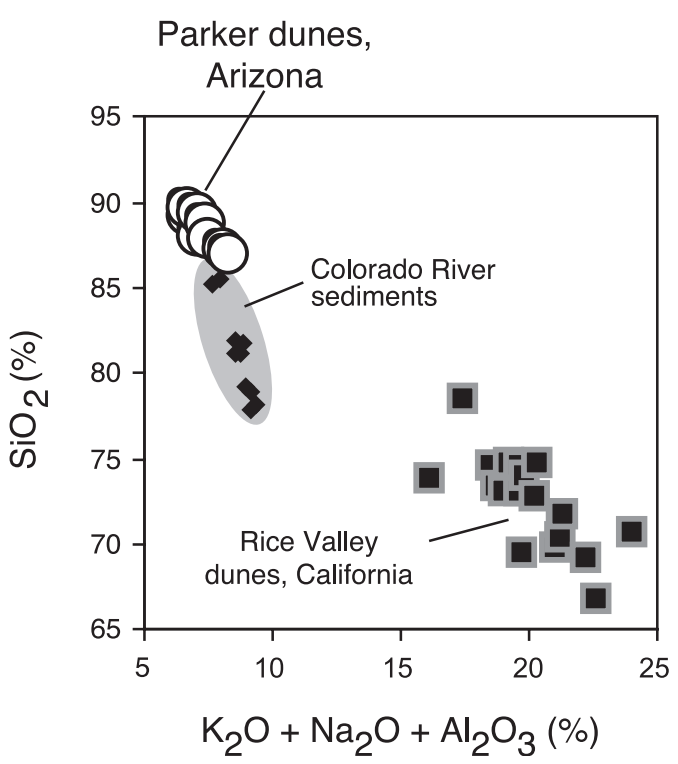

Fig. 4. Plots of $\mathrm{SiO}_{2}$ and $\mathrm{K}_{2} \mathrm{O}+\mathrm{Na}_{2} \mathrm{O}+\mathrm{Al}_{2} \mathrm{O}_{3}$ contents (weight percent) for bulk aeolian sands of the Algodones dunes and Rice Valley dunes, California, the Parker dunes, Arizona, and Colorado River and Whitewater River sediments. Sediments of Whitewater River were previously hypothesized to be a source for the Algodones dunes (see Muhs et al., 1995). 
Great Plains (Fig. 3) of eastern Colorado and Wyoming are good examples of this degree of mineralogical maturity. Although both dunefields have histories at least as old as last-glacial time (Albanese, 1974; Muhs et al., 1996), most dunes date to the late Holocene (less than about 3000 years BP) and are very likely derived directly from their immediate sources.

Dunefields occupy large areas of eastern Colorado adjacent to the South Platte River (Fig. 5). The South Platte River and its tributaries drain the Colorado Front Range and flow eastward. Granodiorites and gneisses that make up the Front Range have typical upper-crust compositions, with $\mathrm{SiO}_{2}$ contents ranging from $59 \%$ to $79 \%$ and $\left(\mathrm{K}_{2} \mathrm{O}+\mathrm{Na}_{2} \mathrm{O}+\mathrm{Al}_{2} \mathrm{O}_{3}\right)$ contents ranging from $17 \%$ to $27 \%$ (Fig. 6 ). However, quartzrich sands from more mineralogically mature sedimentary rocks are found in the foothills near the mountain front (e.g., the Fountain Formation of Pennsylvanian age; see van de Kamp and Leake, 1994) and piedmont area (e.g., the Laramie Formation of Cretaceous age) and also contribute sediment to the South Platte River system. Thus, modern South Platte River sands have about equal amounts of quartz and Kfeldspar $(\sim 35 \%$ each $)$, smaller amounts $(\sim 25 \%)$ of plagioclase and about $1-2 \%$ each of biotite and amphibole (van de Kamp and Leake, 1994). A large sand body, the Fort Morgan dunefield, is situated parallel to, and downwind of the South Platte River in northeastern Colorado. Geomorphic, sedimentologic, mineralogic, and geochemical data show that the Fort Morgan dunefield is derived directly from sediments of the South Platte River (Muhs et al., 1996). Fort Morgan dune sands have $\mathrm{SiO}_{2}$ contents that are $77-85 \%$ and $\left(\mathrm{K}_{2} \mathrm{O}+\mathrm{Na}_{2} \mathrm{O}+\mathrm{Al}_{2} \mathrm{O}_{3}\right)$ contents that are

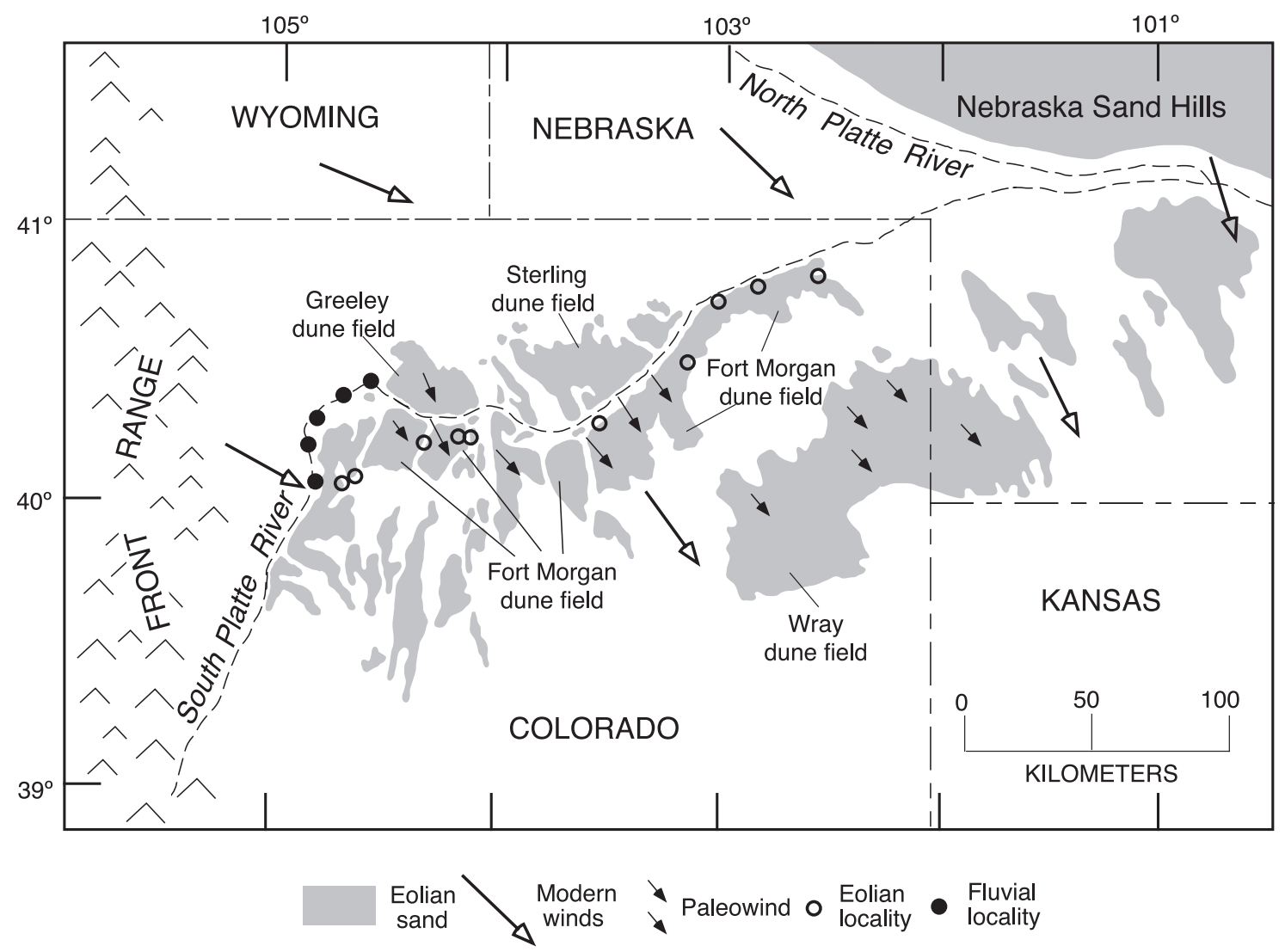

Fig. 5. Map showing the distribution of aeolian sand (grey areas) in northeastern Colorado and adjacent parts of southwestern Nebraska, modern sand roses, late Holocene paleowinds inferred from orientations of parabolic dunes and sample localities for the present study. Dune and wind data taken from Muhs et al. (1996). 

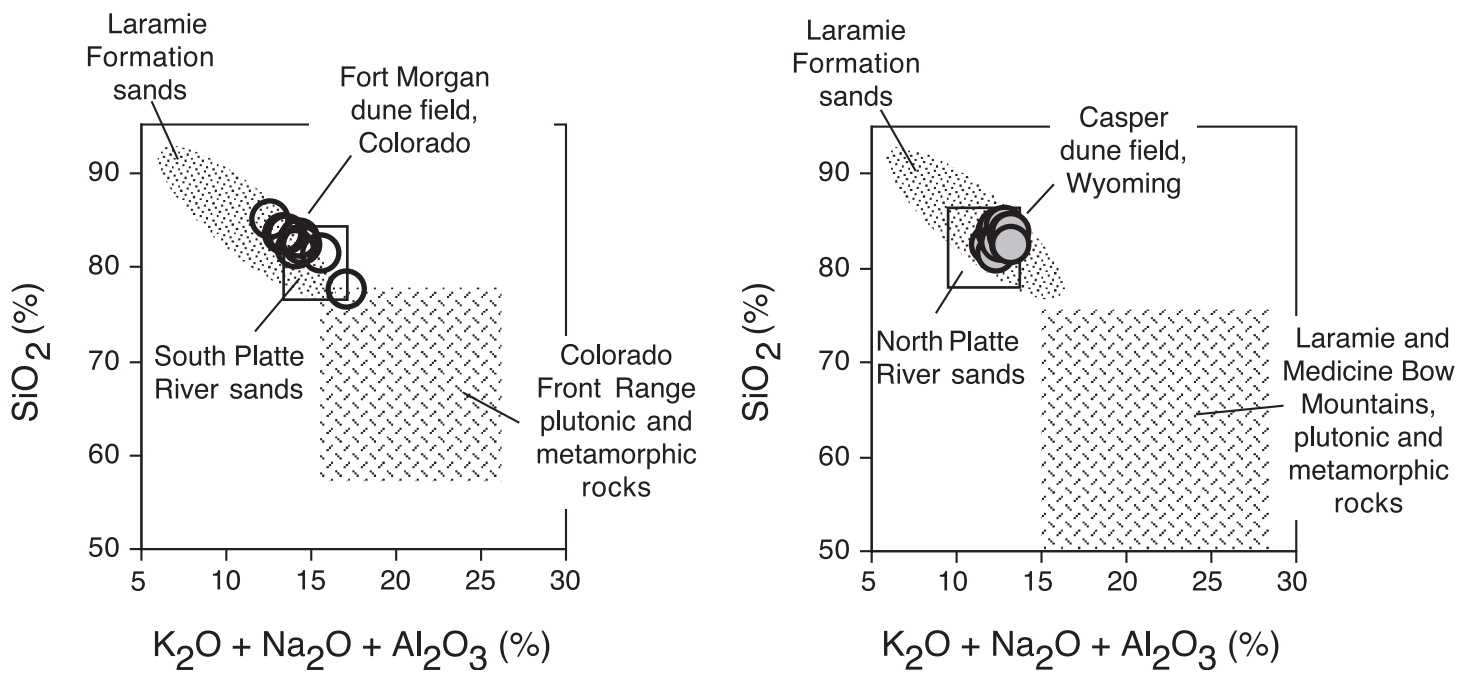

Fig. 6. Plots of $\mathrm{SiO}_{2}$ and $\mathrm{K}_{2} \mathrm{O}+\mathrm{Na}_{2} \mathrm{O}+\mathrm{Al}_{2} \mathrm{O}_{3}$ contents (weight percent) for bulk aeolian sands of the Fort Morgan, Colorado and Casper, Wyoming dunefields, South Platte and North Platte River sediments, the Cretaceous Laramie Formation, and bulk rock samples from the Front Range (Colorado), Laramie Range (Wyoming) and Medicine Bow Mountains (Wyoming). Geochemical data for aeolian sands, Laramie Formation sands and river sediments are from the present study; geochemical data for granitic and metamorphic rocks of the mountains are from Sims and Gable (1967), Gable (1980), Geist et al. (1989), Aleinikoff et al. (1993), and Houston and Marlatt (1997).

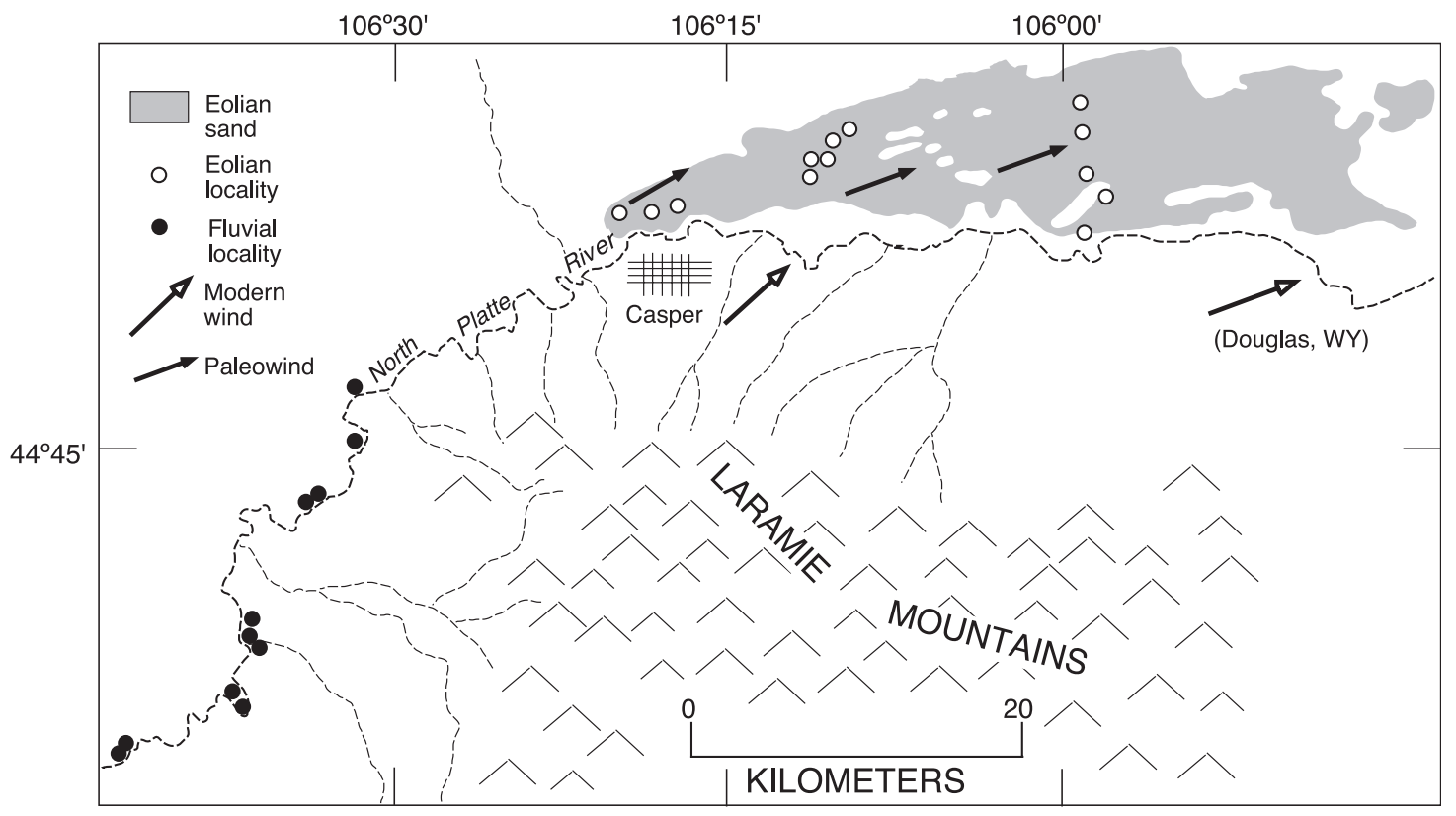

Fig. 7. Map showing the distribution of aeolian sand (grey areas) in the Casper dunefield of Wyoming (from Kolm, 1974, as modified by Love and Christiansen, 1985), modern sand roses, late Holocene paleowinds inferred from orientations of parabolic dunes and sample localities for the present study. Modern sand roses generated by the author; paleowinds inferred from orientations of late Holocene parabolic dunes. 
$12-17 \%$. South Platte River sediments have an almost identical range of values for these elements (Fig. 6). Thus, because of derivation from both plutonic rocks and more-mature sedimentary rocks, sediments of the South Platte River do not have quite the mineralogical maturity of Colorado River sediments. Consistent with this, the Fort Morgan dunes have a somewhat lower degree of mineralogical maturity than either the Parker dunes or Algodones dunes.

A situation similar to that of eastern Colorado is seen in the composition of sands in the Casper dunefield of eastern Wyoming (Fig. 7). Stratigraphic investigations by Albanese (1974) demonstrate that the dunefield may be at least as old as $\sim 10000{ }^{14} \mathrm{C}$ years BP. The most recent episodes of aeolian sand movement are probably much younger, however. Observations of surface soils made during the present study show that the degree of development is minimal, with only A/AC/C profiles, similar to those soils that date to the late Holocene in adjacent parts of Colorado and Nebraska (Muhs et al., 1996, 1997a). Albanese (1974) speculated that the Casper dunefield was probably derived from the North Platte River, a hypothesis that is supported by the present study. Orientations of late Holocene dunes are consistent with modern winds, which are mainly from the southwest. The North Platte River is south and southwest of the dunes and aeolian sand is absent on the

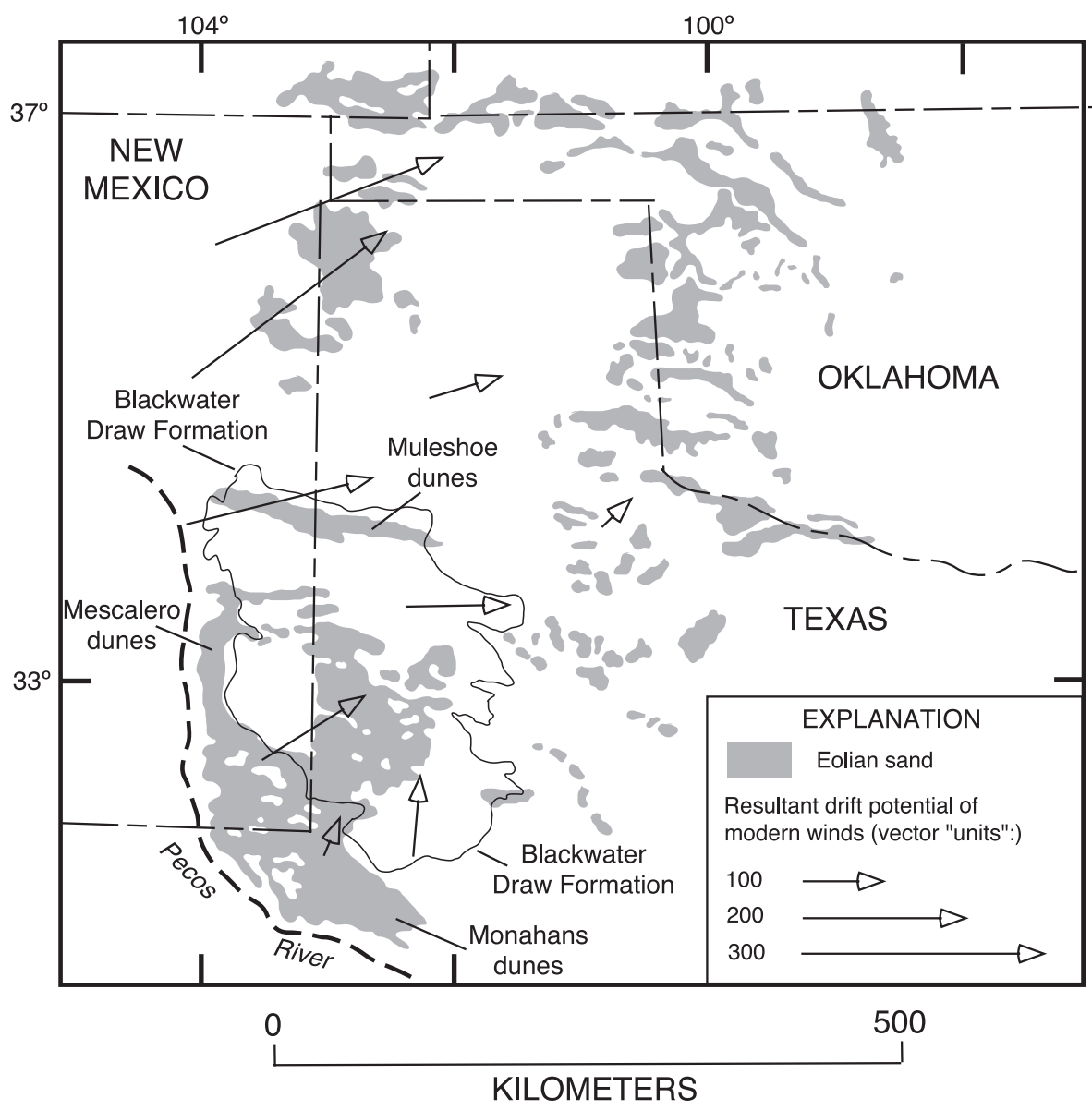

Fig. 8. Map showing the distribution of aeolian sand (grey areas) in the Southern High Plains of Texas, New Mexico and Oklahoma, names of dunefields studied, and modern sand roses. Aeolian sand distribution from compilation by Muhs and Holliday (1995); sand roses are from Muhs and Holliday (2001). Also shown (thin solid line) is the distribution of the sandy or loamy facies of the Blackwater Draw Formation (from Holliday, 1989). 
south side of the river (Fig. 7). Albanese (1974) reported that aeolian sand in the Casper dunefield, at least at one site, is dominated by quartz, but contains up to $40 \%$ non-quartz components, including feldspars, schist fragments and chert. Major element chemistry supports this composition, as Casper dune sands sampled in the present study have $81-84 \%$ $\mathrm{SiO}_{2}$, similar to aeolian sands of the Fort Morgan dunefield of eastern Colorado (Fig. 6) and nearly identical to sediments of the North Platte River.

\subsection{Mature dunefields with quartz enrichment by} ballistic impacts: Southern High Plains of Texas and New Mexico and the Nebraska Sand Hills

Not all Great Plains dunefields have intermediate degrees of mineralogical maturity. Indeed, some dunefields of the Great Plains have an abundance of quartz that is similar to, or even exceeds that of Sonoran Desert aeolian sands derived from the Colorado River. The Southern High Plains of Texas and New Mexico are occupied by some of the largest dunefields of the region (Fig. 8). A recent study by Muhs and Holliday (2001) showed that the sands of these dunefields are very high in quartz and very low in plagioclase and $\mathrm{K}$ feldspar. Dune orientations and modern wind directions (Fig. 8) indicate that the source of the dunes lies to the southwest and could be either sediments of the Pecos River or, at least in the case of the northernmost dunefields, the Blackwater Draw Formation. The Blackwater Draw Formation, described in detail by Holliday (1989), consists of aeolian sheet sands over most of its extent in the Southern High Plains, and may have a 1.4-million-year history.

The Muleshoe dunefield of the Southern High Plains appears to have a maturity that is inherited. On the basis of several lines of evidence, Muhs and Holliday (2001) concluded that sands of the Muleshoe dunefield are probably derived mostly from the Blackwater Draw Formation. Sands of the Muleshoe dunefield are $94-97 \% \mathrm{SiO}_{2}$ and most have $\left(\mathrm{K}_{2} \mathrm{O}+\right.$ $\mathrm{Na}_{2} \mathrm{O}+\mathrm{Al}_{2} \mathrm{O}_{3}$ ) contents of $2-4 \%$, which makes them highly mature mineralogically (Fig. 9). Sands of the Blackwater Draw Formation are $94-96 \% \mathrm{SiO}_{2}$, virtually an identical range as the dunes, indicating that, like the Algodones and Parker dunes, the mineralogical maturity of the Muleshoe dune sand is probably largely inherited.

Further south, the Monahans dunefield has an origin that is not as easily explained as that of the Muleshoe dunefield. Much of the Monahans field occurs upwind of the known extent of the sandy facies of the Blackwater Draw Formation (Fig. 8), although Muhs and Holliday (2001) pointed out that
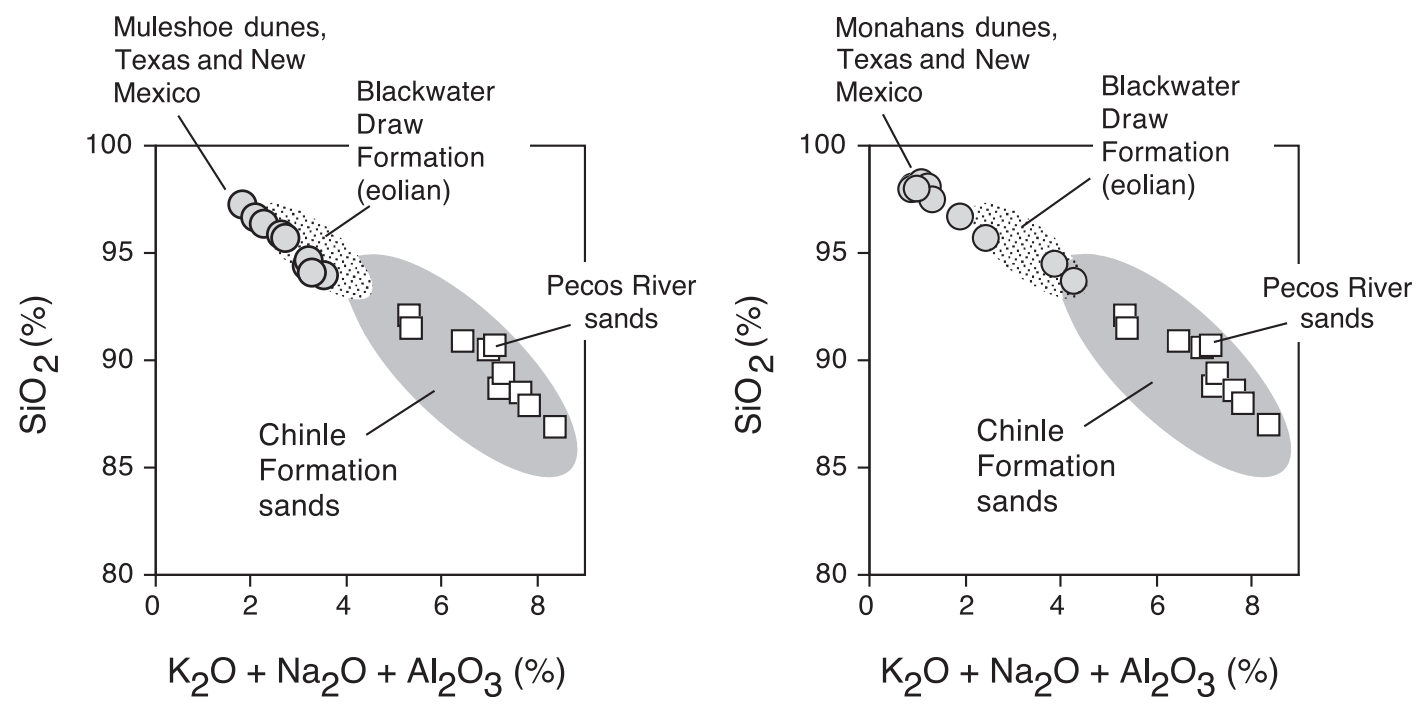

Fig. 9. Plots of $\mathrm{SiO}_{2}$ and $\mathrm{K}_{2} \mathrm{O}+\mathrm{Na}_{2} \mathrm{O}+\mathrm{Al}_{2} \mathrm{O}_{3}$ contents (weight percent) for bulk aeolian sands of the Muleshoe and Monahans dunefields, Pecos River sediments and sediments of the Blackwater Draw (Pleistocene) and Chinle (Triassic) Formations. 
an older aeolian sand unit, called the Judkins Formation, occurs beneath the Monahans dunes. The Judkins Formation has not been studied in great detail, but where exposed, it appears to have many characteristics of the Blackwater Draw Formation. Muhs and Holliday (2001) suggested that the Judkins Formation, plus sediments from the Pecos River, are the likely sources for the Monahans sands. The Monahans dune sands are, however, on average more mature mineralogically than any possible source sediment (Fig. 9). The $\mathrm{SiO}_{2}$ contents of the Monahans dunes are 94$98 \%$ and most have $\left(\mathrm{K}_{2} \mathrm{O}+\mathrm{Na}_{2} \mathrm{O}+\mathrm{Al}_{2} \mathrm{O}_{3}\right)$ contents of $2 \%$ or less, indicating a mineralogy dominated by quartz. The Triassic Chinle Formation (which occu- pies much of the Pecos River basin), Pecos River sands, and sands of the Blackwater Draw Formation are all relatively high in quartz, as indicated by $\mathrm{SiO}_{2}$ and $\left(\mathrm{K}_{2} \mathrm{O}+\mathrm{Na}_{2} \mathrm{O}+\mathrm{Al}_{2} \mathrm{O}_{3}\right)$ contents, yet none is as quartz-enriched as the Monahans dunes (Fig. 9). Quartz enrichment in the Monohans dunes is, therefore, due to some process that has taken place within the dunefield itself.

The Nebraska Sand Hills region of the central Great Plains is the largest dunefield in North America (Figs. 3 and 10). Lugn (1968) stated, without much supporting evidence, that sand from Ogallala Group (Tertiary) rocks was the source of sediment for the Nebraska Sand Hills, as well as for other dunefields

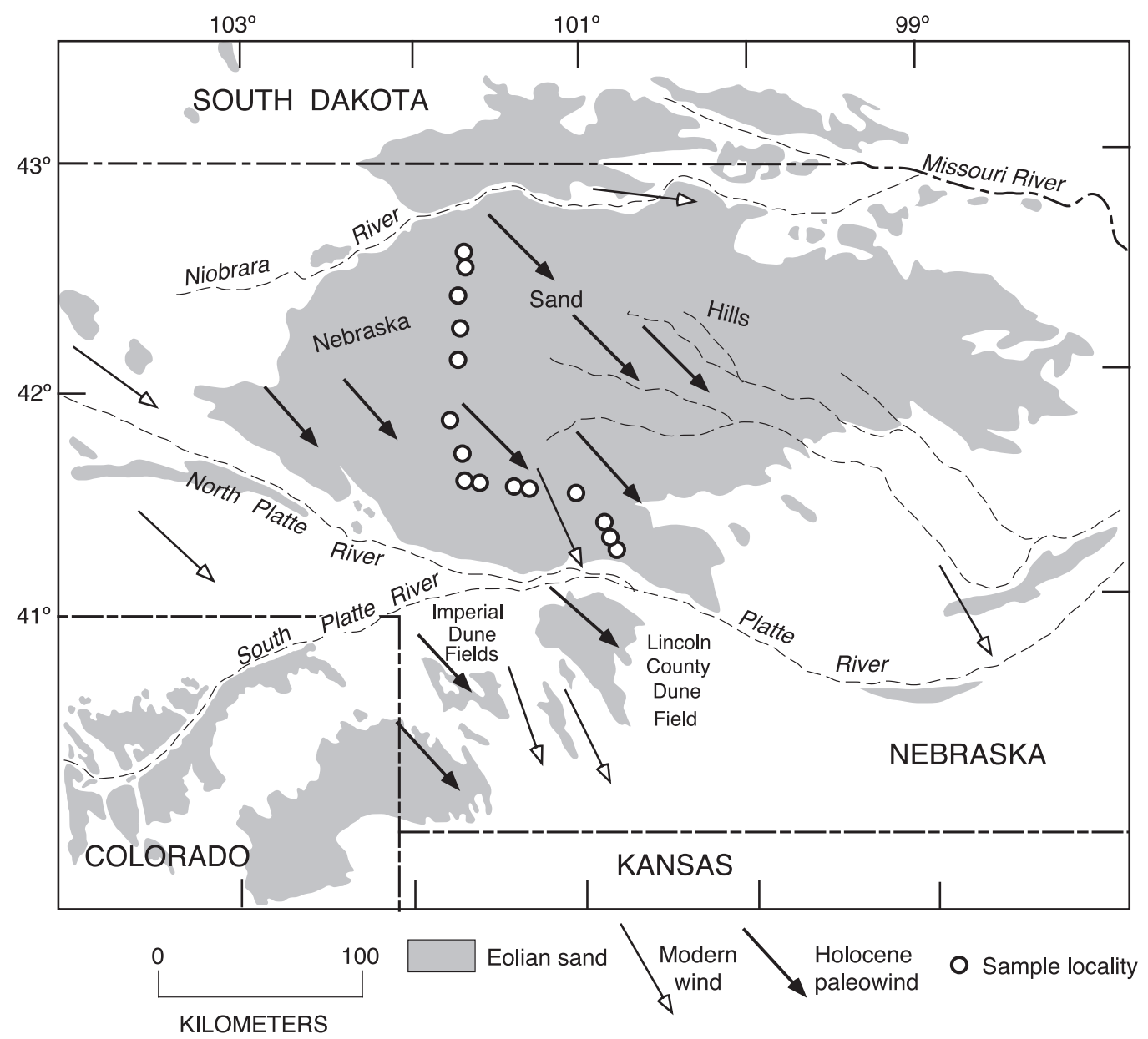

Fig. 10. Map showing the distribution of aeolian sand (grey areas) in the Nebraska Sand Hills and adjacent areas (compiled from Swinehart, 1990 and Muhs et al., 1996, 2000), modern sand roses, inferred late Holocene paleowinds, and sample localities. Modern sand roses generated by the author; inferred late Holocene paleowinds from aerial photograph interpretation. 
on the Great Plains. However, $\mathrm{Pb}$-isotopic compositions of $\mathrm{K}$-feldspars and $\mathrm{U}-\mathrm{Pb}$ ages of zircons indicate that the Ogallala Group cannot be the sole source of the Nebraska Sand Hills (Aleinikoff et al., 1994). Other possible source sediments include: (1) Arikaree Group rocks (Tertiary), which crop out to the north and northwest of the Sand Hills; (2) aeolian sheet sands (Pliocene) that underlie the Sand Hills; (3) sands from the North Platte River; and (4) sands from the upper Niobrara River (Fig. 10).

Geochemical data indicate that Nebraska Sand Hills dunes, like sands of the Monahans dunefield, are enriched in quartz compared to their possible source sediments (Fig. 11). There is overlap in the compositions of the dune sands and the compositions of Ogallala Group sands, Arikaree Group sands and Pliocene sheet sands, but on average, the aeolian sands are more mature. The degree of feldspar depletion also increases from northwest to southeast (Fig. 12). Plots of $\mathrm{Al}_{2} \mathrm{O}_{3}$ (all feldspars), $\mathrm{CaO}$ (calcic plagioclase, as calcite is absent in these dunes), and $\mathrm{Na}_{2} \mathrm{O}$ (sodic plagioclase) concentrations indicate that distance downwind from the Niobrara River shows a significant degree of explanation (60-86\%) for feldspar content. Overall, the northwest-to-southeast depletion of feldspar is consistent with both northwesterly modern winds and northwesterly late Holocene paleowinds (Fig. 10).
The relative maturity of the Texas and Nebraska dunefields could be the result of long periods of stability such that chemical weathering has depleted feldspars and enriched the sands in quartz. However, this mechanism would require not only long periods of dune stability, but also relatively humid paleoclimates, such that chemical weathering would proceed at a rate rapid enough to deplete feldspars over a Quaternary time scale. Long-term paleoclimate records from nearby loess-paleosol sequences in Colorado and Nebraska and the morphology of paleosols in the Blackwater Draw Formation (which spans the past 1.4 Ma) indicate that the Great Plains region has probably been semiarid to subhumid for a long time (Holliday, 1989, 1995; Muhs et al., 1999).

A more likely explanation is that quartz enrichment takes place by aeolian processes within the dunefields themselves. Dutta et al. (1993) showed, on the basis of both theoretical calculations and wind tunnel experiments, that sand-sized K-feldspar grains are reduced in size on impact when wind velocities exceed $10 \mathrm{~m}$ $\mathrm{s}^{-1}$. In Nebraska, eastern Colorado and Texas, winds are persistent and strong. For example, in areas around the Nebraska Sand Hills, winds that exceed velocities of $10 \mathrm{~m} \mathrm{~s}^{-1}$ occur approximately $5-13 \%$ of the time (Muhs et al., 1997a). Thus, over geologic time periods, significant loss of feldspars can occur within the dunefield itself by ballistic impacts. In addition, at
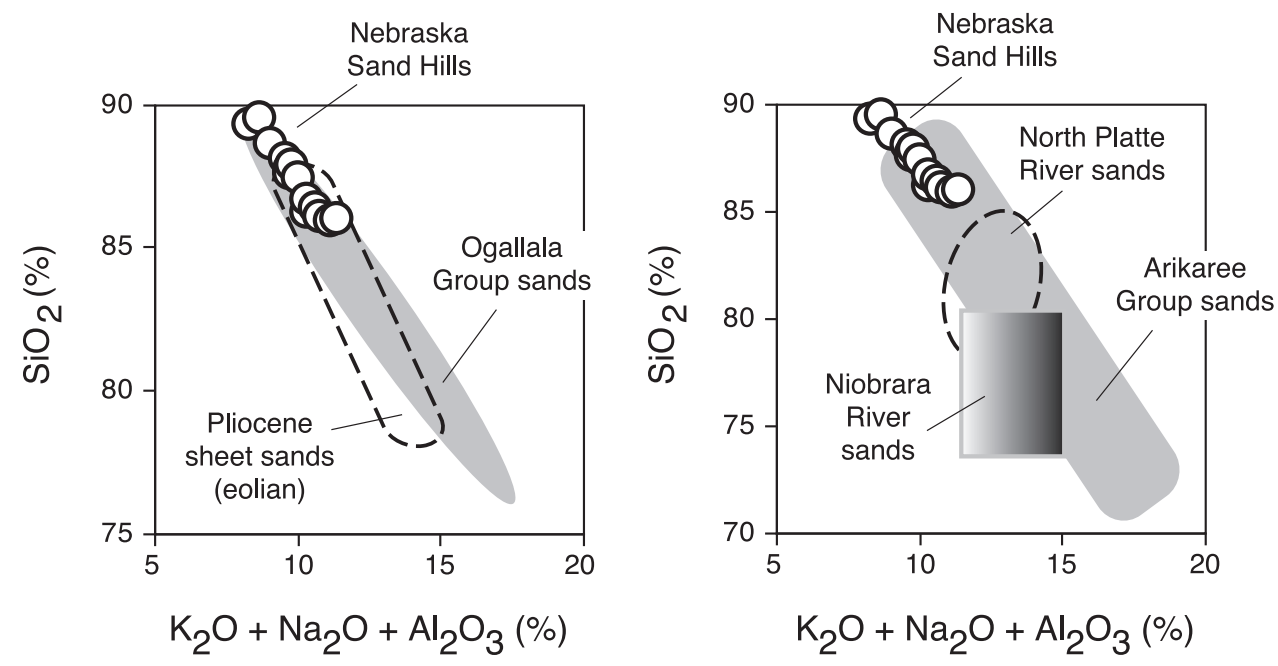

Fig. 11. Plots of $\mathrm{SiO}_{2}$ and $\mathrm{K}_{2} \mathrm{O}+\mathrm{Na}_{2} \mathrm{O}+\mathrm{Al}_{2} \mathrm{O}_{3}$ contents (weight percent) for bulk aeolian sands of the Nebraska Sand Hills and possible source sediments. 

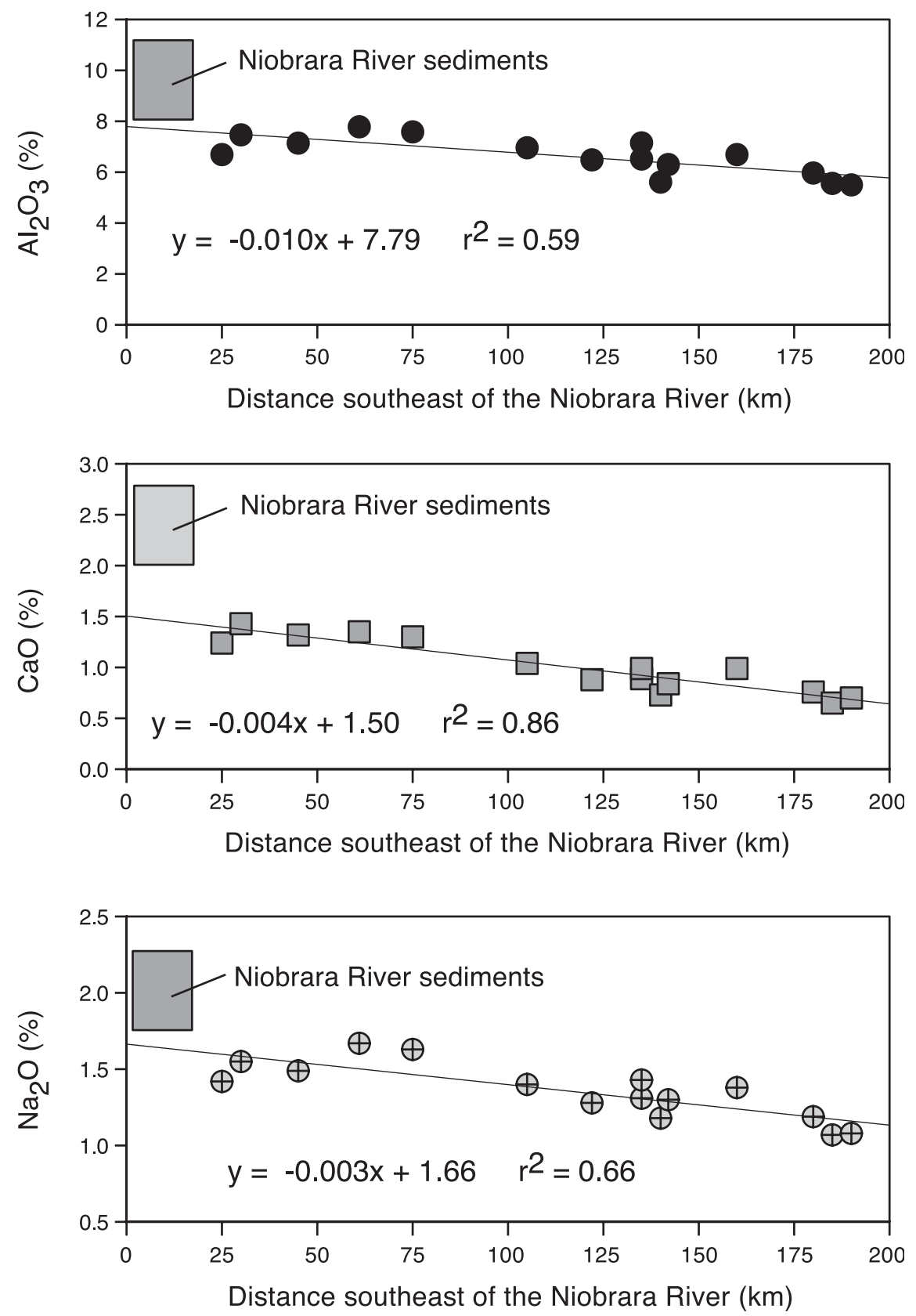

Fig. 12. Plots of major elements $\left(\mathrm{CaO}, \mathrm{Na}_{2} \mathrm{O}\right.$, and $\left.\mathrm{Al}_{2} \mathrm{O}_{3}\right)$ that are proxies for feldspar shown as a function of distance downwind from the northwestern part of the Nebraska Sand Hills, near the Niobrara River (localities shown in Fig. 10). Shown for comparison are the ranges in composition of Niobrara River sediments $(250-53 \mu \mathrm{m}$ fraction) upstream of the Nebraska Sand Hills. Note that distance downwind from the Niobrara River is used as a geographic point of convenience and does not imply that the river is the sole source of the dune sand. 
least in Nebraska, softer minerals such as calcite may have been reduced to silt sizes by abrasion. Most of the possible source sediments for the Nebraska Sand Hills contain carbonates, but calcite was not found in any of the dunes studied.

Reduction of sand-sized feldspars and carbonate minerals to silt-sized particles within a dunefield allows the smaller particles to be removed from the dunefield by suspension, leaving behind a quartz-rich residue. One implication of these observations is that dunefields can, in theory, serve as partial sources of loess that is found downwind, such as in Nebraska. However, a broader implication of the ballistic impact process is that dunefields in this region have been active for longer periods than they have been stable over their histories.

\section{Mineralogical maturity in dunefields of Africa and Australia}

Aeolian sand is extensive over much of Africa and Australia and some of the best-studied dunefields in the world are found on these continents. New geochemical data for three dunefields are presented here, along with hypotheses to explain their degree of mineralogical maturity. The sediments studied are from the Zallaf sand sea in Libya (Fig. 13), the Namib sand sea in southern Africa (Fig. 14), and the Great Sandy Desert in Australia (Fig. 15). The samples analyzed in the study are from collections made by E.D. McKee and archived with the U.S. Geological Survey in Denver, $\mathrm{CO}$. It is not argued that the samples analyzed here are necessarily the most representative for these dunefields. The interpretations made from these analyses are presented merely as hypotheses for testing with further field and laboratory work.

\subsection{Zallaf sand sea of Libya}

Some of the world's largest dunefields are found in the Sahara Desert. The Zallaf sand sea is found in the Marzuq structural basin of southwestern Libya and is the eastern arm of the Sahra Awbari sand sea. It is north of the larger Sahra Marzuq sand sea (Fig. 14). The Sahra Awbari and Zallaf sand seas are characterized by sand sheets, linear dunes and barchanoid ridges (Breed et al., 1979).
Walker (1979) speculated that dune sand sources for the Sahra Awbari lay to the northeast of the sand sea, which is consistent with one set of dune orientations (Fig. 13). He pointed out that dunes become redder in a southwesterly direction, a process he attributed to greater age and greater distance from the source. If this interpretation is correct, it indicates that dunes of the Zallaf sand sea lie relatively close to their source and are younger than the red dunes found farther to the southwest. Such a scenario implies that dunes of the Zallaf sand sea could be relatively immature mineralogically.

The Zallaf sand sea samples used in this study (McKee's \#DS-705, 708, 717, 718 and 720) are from an active linear dune near Sebhah, described in detail by McKee and Tibbitts (1964). Textural analysis of these samples, reported by Ahlbrandt (1979), indicates that mean grain sizes range from 1.4 to 2.2 phi, or medium to fine sand. In the present study, X-ray diffraction analysis indicates that two samples (DS705 and DS-718) contain only quartz; the other three samples are dominantly quartz, but contain trace quantities of feldspar, probably K-feldspar. Thus, the sands are very mature mineralogically and are probably quartz arenites. Geochemical analyses support this conclusion, as the samples are $97.9-98.5 \% \mathrm{SiO}_{2}$ and $\left(\mathrm{K}_{2} \mathrm{O}+\mathrm{Na}_{2} \mathrm{O}+\mathrm{Al}_{2} \mathrm{O}_{3}\right)$ contents are less than $1 \%$ (Fig. 16).

The Awbari and Zallaf sand seas are situated to the south of uplands composed of Paleozoic (CambrianOrdovician) sedimentary rocks, chiefly sandstone, and north of a desert plain underlain by what was formerly referred to as the "Nubian Sandstone" of Mesozoic age. The upper part of the Nubian Sandstone is now called the Messak Sandstone (Conant and Goudarzi, 1967; Lorenz, 1980). Cambrian-Ordovician sandstones of the central Sahara are, in their upper parts, dominantly quartzose sandstones capped by finegrained quartzites. Although feldspars are found in parts of the Nubian Sandstone, Hea (1971) emphasizes that much of the Precambrian, Paleozoic and Mesozoic rock record of north Africa consists of hundreds to thousands of meters of nearly pure quartz sand. The Messak (=Nubian) Sandstone underlying the Kallaf sand sea is composed dominantly, if not wholly, of quartz (Lorenz, 1980).

Although Walker's (1979) hypothesis would suggest that dunes in the Kallaf sand sea, because they 


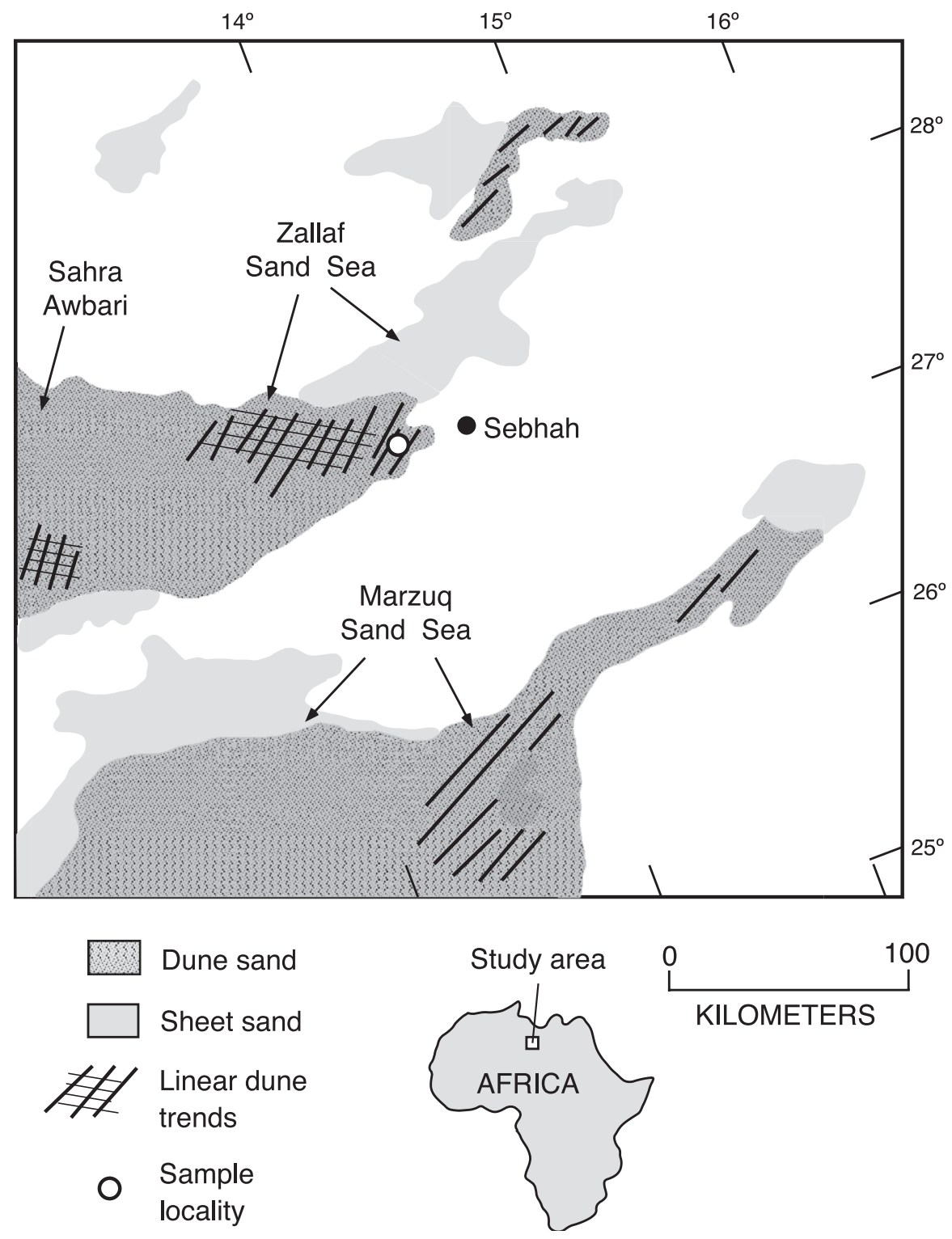

Fig. 13. Map showing the distribution of aeolian sand, in both dunes and sheets, in the Zallaf sand sea and the northern part of the Marzuq sand sea of Libya. Aeolian sand distribution and dune trends from McKee and Tibbitts (1964) and Breed et al. (1979).

lack red colors, are relatively young, the mineralogical and geochemical data presented here indicate they are mineralogically mature. Nevertheless, mineralogically mature but young dunes need not be a contradiction if the source sediment is an alreadymature quartz-dominated sandstone. The hypothesis of quartz inheritance from sandstone for the Zallaf sand sea presented here needs testing, with specific sampling targeted at bedrock sources in the vicinity of the dunefield.

\subsection{Namib sand sea, Namibia}

The Namib sand sea (Fig. 14) occupies much of the Atlantic coast of Namibia and has a total area of $\sim 34000 \mathrm{~km}^{2}$ (Barnard, 1973). It has been studied 


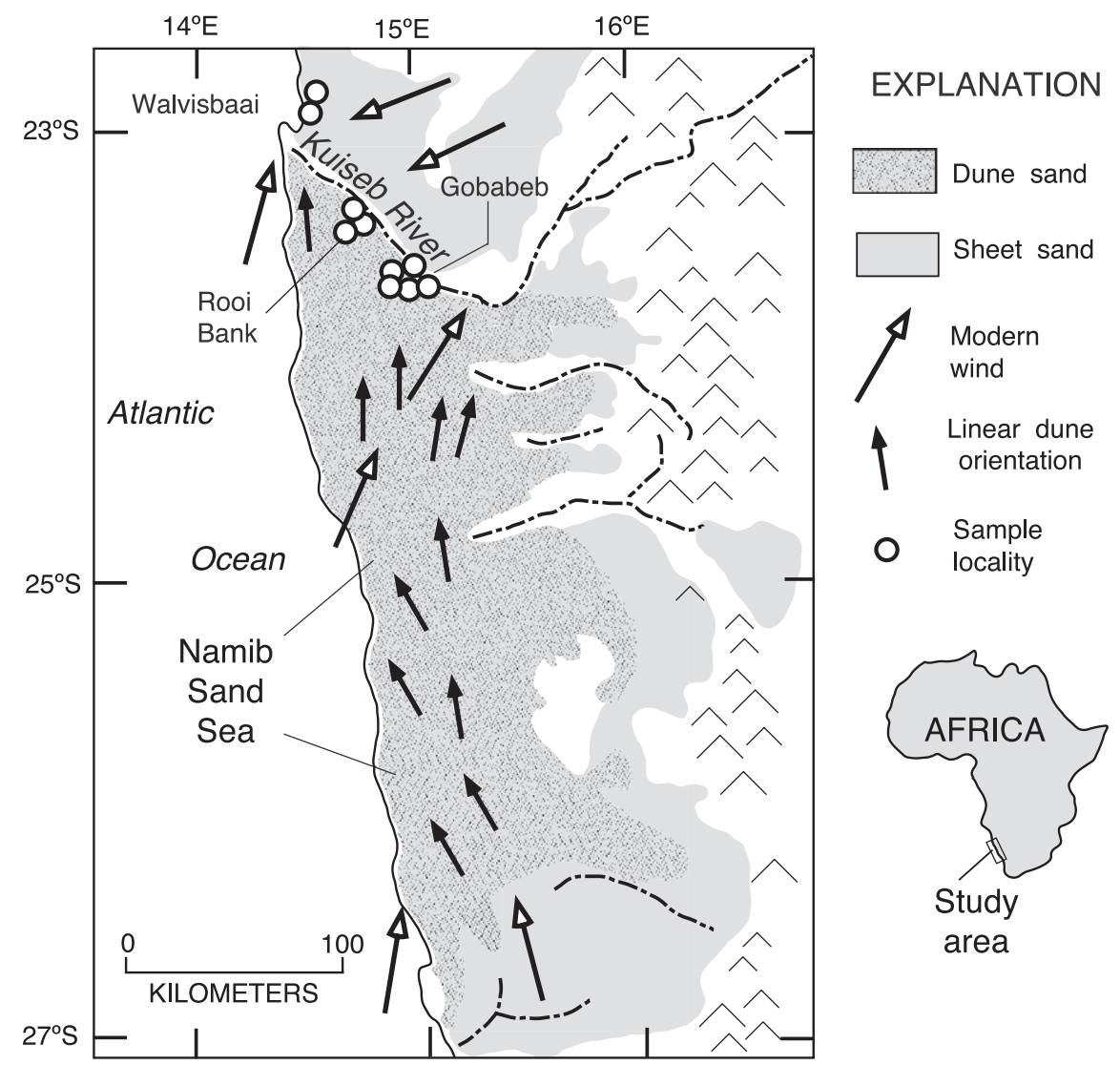

Fig. 14. Map showing the distribution of aeolian sand, in both dunes and sheets, in the Namib sand sea, Namibia, modern winds, inferred paleowinds and sample localities. Aeolian sand distribution and all wind data compiled from Breed et al. (1979) and Lancaster (1989).

by many workers, including Goudie (1970), Barnard (1973), Breed et al. (1979), McKee (1982), Livingstone (1987) and Lancaster (1989). A wide variety of aeolian landforms can be found in the Namib sand sea, including barchanoid ridges, linear dunes, linear dunes with superimposed star dunes, and sand sheets (Breed et al., 1979; McKee, 1982; Livingstone, 1987; Lancaster, 1989). Dune orientations indicate that major dune-forming winds came mainly from the south, which is consistent with modern resultant drift directions (Fig. 14). Lancaster (1989) has shown that the dune sediments vary spatially. Dunes become redder, and particles become more rounded and better sorted in a west-to-east direction, suggesting that the youngest sediments are near the coast and older sediments are found inland.

Most samples analyzed for this study are from linear dunes south of the Kuiseb River, in the northern part of the Namib sand sea, near Rooi Bank and Gobabeb (Fig. 14). Modal particle sizes are coarse to medium sands (McKee, 1982). Microscopic examination of selected samples indicates that although quartz is the dominant mineral, both feldspars and rock fragments are present in significant amounts. X-ray diffraction analyses confirm the presence of quartz as the most important mineral, but all samples have abundant plagioclase and K-feldspar. In addition, a few samples appear to have trace amounts of calcite and dolomite. Geochemical analyses support the mineralogical data, as $\mathrm{SiO}_{2}$ contents are $81-87 \%$ and $\left(\mathrm{K}_{2} \mathrm{O}+\mathrm{Na}_{2} \mathrm{O}+\mathrm{Al}_{2} \mathrm{O}_{3}\right)$ contents are $7-10 \%$ (Fig. 16). One sample from Rooi Bank, not shown in Fig. 16, had an unusually low $\mathrm{SiO}_{2}$ content of $\sim 71 \%$. Overall, the data presented here indicate that Namib dune sediments, at least in the northern part of the sand sea, have an intermediate level of mineralogical 


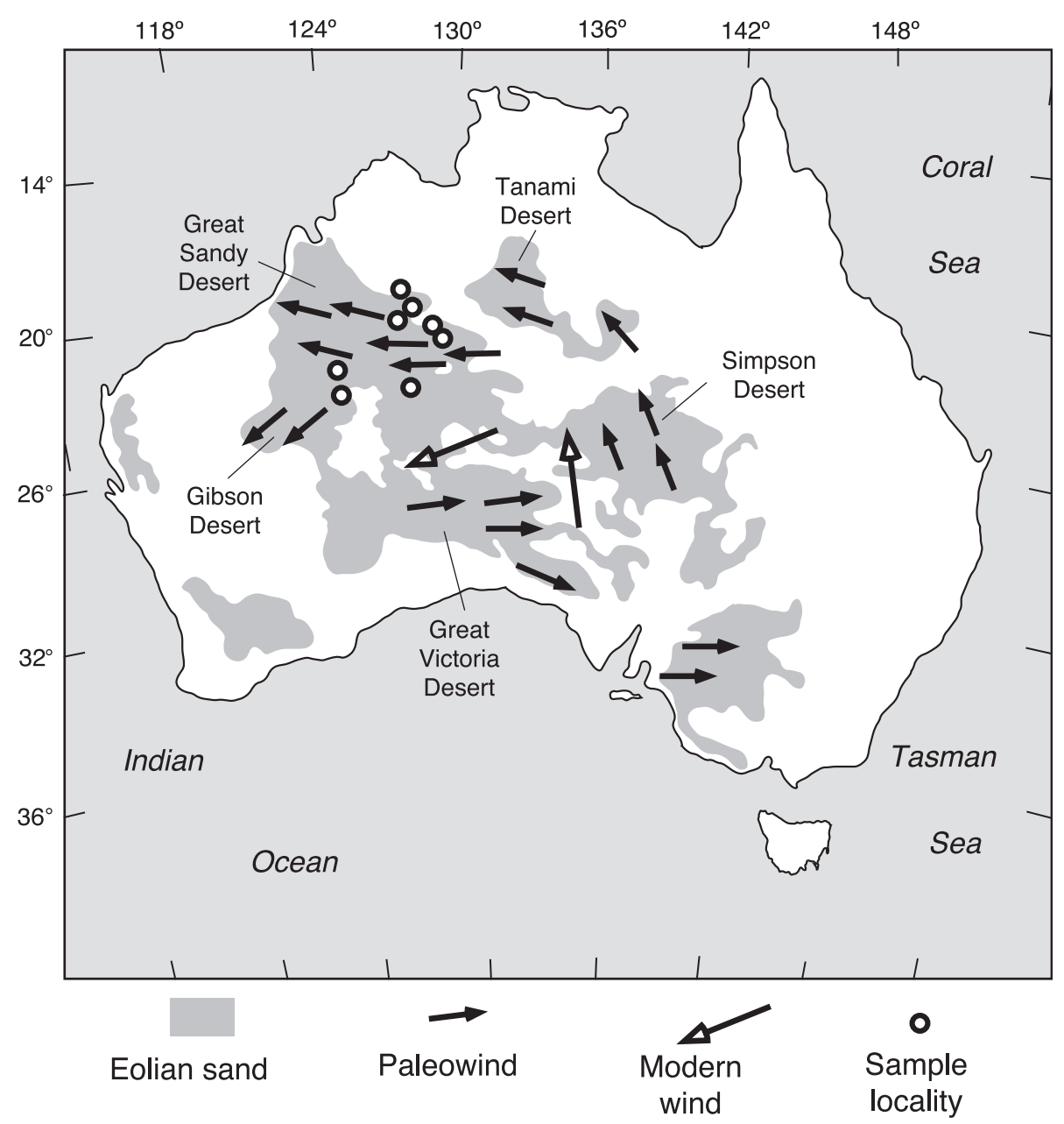

Fig. 15. Map showing the distribution of aeolian sand (grey areas) in Australia, modern sand roses, inferred paleowind directions and sample localities. Aeolian sand distribution and inferred paleowinds from Bowler et al. (2001); modern winds are generalized from sand roses generated by Fryberger and Dean (1979).

maturity, a conclusion also reached by Lancaster (1989).

Most workers now believe that much of the Namib sand sea is derived from coastal sediments in the southern part of the region, in turn derived from the Orange River (see review in Lancaster, 1989). This river heads in Lesotho, flows across South Africa, and terminates in the Atlantic Ocean to the south of the sand sea. The Orange River and its tributaries, such as the Vaal River, drain a wide variety of rock types, including basalt, sedimentary rocks, gneisses and granites (De Villiers et al., 2000). Despite relatively high rainfall in the upper part of the drainage basin, low dissolved loads in the Orange River imply relatively low chemical weathering rates (De Villiers et al., 2000). Thus, it can be hypothesized that fluvial sediments deposited on the coast are relatively immature mineralogically. The intermediate degree of mineralogical maturity of Namib dune sands is consistent with a coastal source of sands, which were delivered by the Orange River.

\subsection{Great Sandy Desert, western Australia}

Much of the arid interior of Australia is covered with large fields of predominantly linear dunes 

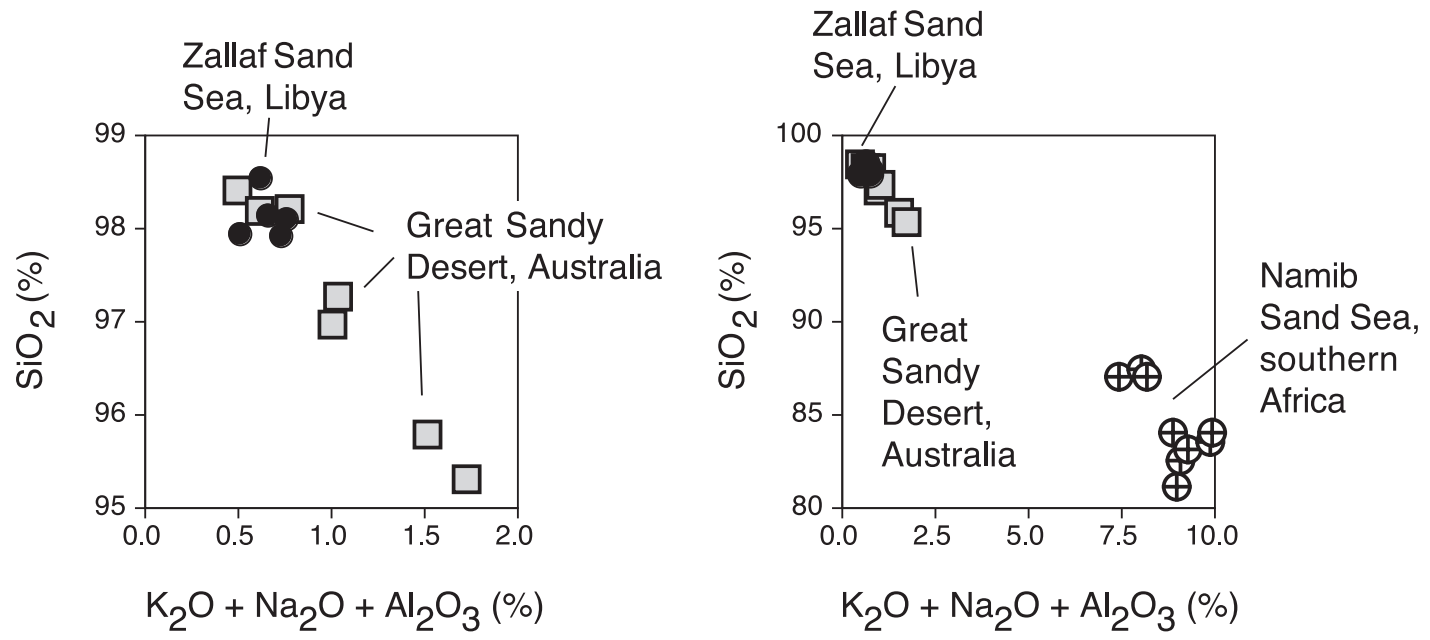

Fig. 16. Plots of $\mathrm{SiO}_{2}$ and $\mathrm{K}_{2} \mathrm{O}+\mathrm{Na}_{2} \mathrm{O}+\mathrm{Al}_{2} \mathrm{O}_{3}$ contents (weight percent) for bulk aeolian sands of the Zallaf sand sea, Libya, Great Sandy Desert, Australia, and Namib sand sea, Namibia. Plot on left has been rescaled to show differences between Libyan and Australian sands. Not shown is one sample from the Namib sand sea with $\sim 71 \% \mathrm{SiO}_{2}$.

(Fig. 15). In general, dune trends show good agreement with modern dune-forming winds. However, most dunes in Australia are not active at present. The most recent episodes of dune-building were during the last glacial period (Wasson, 1986; Goudie et al., 1993; Nanson et al., 1995). In addition, recent studies by Bowler et al. (2001) also suggest that there were several pre-last-glacial periods of dune-building in the Great Sandy Desert, including some that are beyond the $\sim 100000$ years BP limit of luminescence dating.

The Great Sandy Desert, one of the largest dunefields, lies in the Canning Basin, an intracratonic basin that contains as much as $18000 \mathrm{~m}$ of predominantly Paleozoic clastic sediments (Towner and Gibson, 1983). All samples examined in the present study are from linear dunes found in this basin. Average particle sizes range from fine to medium sand (Ahlbrandt, 1979). The sands have dry Munsell colors of 2.5 YR 4/8 or 2.5YR 5/8. Microscopic examination of the sediments shows that the grains are mostly clear quartz with the red color due to an $\sim 10 \%$ coating of clay, silt and/or Fe-oxides, similar to that observed by Goudie et al. (1993).

Mineralogical analysis by both microscopic examination of the grains and X-ray diffraction confirms the findings of Goudie et al. (1993) that aeolian sand of the Great Sandy Desert is dominated by quartz.
Only one sample examined had even the slightest trace of feldspar; all others showed only quartz. Geochemical analyses support these findings, as all samples had $\mathrm{SiO}_{2}$ contents of $95-98 \%$ and $\left(\mathrm{K}_{2} \mathrm{O}+\mathrm{Na}_{2} \mathrm{O}+\mathrm{Al}_{2} \mathrm{O}_{3}\right)$ contents of $0.5-2.0 \%$ (Fig. 16). It is likely, given that quartz was essentially the only sand-sized grain observed, that the small amount of $\mathrm{Al}_{2} \mathrm{O}_{3}(0.5-1.7 \%)$ does not represent feldspars but clay minerals in grain coatings that were not completely removed during pretreatments.

The origin of desert dunes in Australia has been debated intensely. Wasson (1983) suggested that alluvium, lacustrine sediments and bedrock could all be important sources of aeolian sand in the Simpson and Strzelecki Deserts. McTainsh (1989, his Fig. 1) pointed out the close association of dunes in the Simpson, Strzelecki and Tirari Deserts with major river systems, implying a fluvial source for the aeolian sediments in these areas. Nanson et al. (1995) also suggested a fluvial source for dunes in the western Simpson Desert. Such an association is not as apparent in other dunefields, however, such as the Great Sandy Desert, which does not have a major river system situated on its upwind (southeastern) side. Isotopic studies of detrital zircons led Pell et al. $(1999,2000)$ to conclude that aeolian sands in the Great Victoria, Simpson, Strzelecki and Tirari Deserts are derived from local bedrock in the same sedimentary basins in which they 
reside, with very little subsequent aeolian transport. Pell and Chivas (1995) came to a similar conclusion after examining secondary surface features (precipitated silica plates and sheets) on aeolian sand grains from almost all the dunefields of Australia. However, Wopfner and Twidale (2001) challenged the conclusions of Pell et al. $(1999,2000)$ and argued instead for long-distance aeolian transport of sand.

The high degree of mineralogical maturity of the sands in the Great Sandy Desert presents at least three possible interpretations. If the sands have experienced a long period of stability, this could explain the high content of kaolinite-hematite clay coatings, which might have resulted from in situ weathering of sandsized feldspar (as suggested by Goudie et al., 1993, p. 316). A second possibility is that the mineralogical maturity is due to long-distant transport of sand (as suggested by Wopfner and Twidale, 2001), with feldspar loss from ballistic impacts. However, this mechanism does not explain the presence of the red coatings, which would most likely be abraded away during transport. Muhs and Holliday (2001) noted, for example, that sands in the Muleshoe dunes of Texas and New Mexico have an inherited redness from the Blackwater Draw Formation, but lost much of this redness in a downwind direction. A third possibility is that the mineralogical maturity of the sands is due to inheritance from quartz-rich sandstone sources (as implied by Pell et al., 1999, 2000). Towner and Gibson (1983) mapped two Cretaceous units, the Anketell and Frezier Sandstones, beneath the Great Sandy Desert. These workers did not provide any data on the mineralogy of the units, but a worthwhile effort would be to determine if these rocks are dominated by quartz. If such is the case, then the mineralogical maturity of the dunes could be simply inherited, and the red coatings may indicate a long period of stability, even if there has not been significant chemical weathering.

\section{Summary}

The concepts and new data presented here suggest that studies of dune sand composition can yield valuable clues to a dunefield's origin, if combined with other field and laboratory investigations. Some dunefields have compositions, whether mature or immature, that are direct reflections of their source sediments. Mineralogical maturity in certain dunefields can be inherited directly from quartz-rich source sediments. Examples of such inheritance include the Algodones and Parker dunes of the southwestern United States, the Muleshoe dunes of Texas and New Mexico, and possibly the Zallaf sand sea of Libya and the Great Sandy Desert of Australia. In other cases, dune sands with a lesser degree of mineralogical maturity, derived from large rivers, reflect mixed lithologies in the drainage basin. Examples include the Fort Morgan and Casper dunefields of Colorado and Wyoming, and the Namib sand sea of Africa, where unweathered plutonic and metamorphic rocks, combined with mature sedimentary rocks, yield a source alluvium with an intermediate degree of maturity. Finally, small dunefields in closed desert basins, such as the Rice Valley dunes in California, are fed only by local plutonic rocks, and have the most immature compositions of all.

Other dunefields have compositions that do not reflect their source sediments. If a dunefield has experienced long periods of stability, feldspar loss can occur if the climate is conducive to chemical weathering. Reactivation of the dunes can then introduce a quartz-enriched sediment into transit. Repeated cycles of this sort could ultimately result in a quartzdominated dunefield. Such a mechanism is unlikely for dunefields, in arid and semiarid regions, that experience little chemical weathering. On the other hand, aeolian processes themselves can modify the composition of a dunefield. One such process is abrasion of soft minerals, such as gypsum, calcite and dolomite. Another process is ballistic impacts, which can reduce the size of feldspars. Thus, dunefields such as the Nebraska Sand Hills and the Monahans dunes of Texas and New Mexico have greater mineralogical maturity than any source sediment. Such a state of mineralogical maturity is achieved on a Quaternary time scale not from extended periods of stability and weathering, but from extended periods of aeolian activity.

\section{Acknowledgements}

This study was supported by the U.S. Geological Survey's Earth Surface Dynamics Program and is a contribution to the "Eolian History of North Amer- 
ica" project. I thank Tom Ager, John Aleinikoff, Josh Been, Chuck Bush, Vance Holliday, Zachary Muhs Rowland, Jim Swinehart and Stephen Wolfe for assistance in collecting samples in the Great Plains and desert Southwest over the past 15 years. Chris Schenk kindly provided splits from Ed McKee's archived aeolian sand collections at the USGS, Denver. Josh Been and Scott Cowherd prepared the samples for geochemical analyses and Gary Skipp provided the X-ray data for mineralogy. I am grateful to Andrew Warren, Stephen Stokes, Peter Birkeland and Kathleen Simmons for the helpful comments on an earlier version of the paper. Thanks also go to Ian Livingstone for inviting me to submit the paper and for careful editing in its final stages.

\section{References}

Abegg, F.E., Loope, D.B., Harris, P.M., 2001. Carbonate eolianitesdepositional models and diagenesis. In: Abegg, F.E., Harris, P.M., Loop, D.B. (Eds.), Modern and ancient carbonate eolianites: sedimentology, sequence stratigraphy, and diagenesis. Special Publication - Society for Sedimentary Geology 71, 17-30.

Ahlbrandt, T.S., 1979. Textural parameters of eolian deposits. U.S. Geological Survey Professional Paper 1052, 21-51.

Albanese, J.P., 1974. Geology of the Casper aracheological site. In: Frison, G.C. (Ed.), The Casper Site, A Hell Gap Bison Kill on the High Plains. Academic Press, New York, pp. 174-190.

Aleinikoff, J.N., Reed Jr., J.C., DeWitt, E., 1993. The Mount Evans batholith in the Colorado Front Range: revision of its age and reinterpretation of its structure. Geological Society of America Bulletin 105, 791-806.

Aleinikoff, J.N., Muhs, D.R., Walter, M., 1994. U-Pb evidence for provenances of Holocene sand dunes, northeastern Colorado and the Nebraska Sand Hills. U.S. Geological Survey Circular 1107,2 .

Anton, D., 1983. Modern eolian deposits of the eastern province of Saudi Arabia. In: Brookfield, M.E., Ahlbrandt, T.S. (Eds.), Eolian Sediments and Processes. Developments in Sedimentology, vol. 38. Elsevier, Amsterdam, pp. 365-378.

Arbogast, A.F., Muhs, D.R., 2000. Geochemical and mineralogical evidence from eolian sediments for northwesterly mid-Holocene paleowinds, central Kansas, USA. Quaternary International 67, $107-118$.

Barnard, W.S., 1973. Duinformasies in die Sentrale Namib. Tegnikon 5, 2-13.

Basu, A., 1976. Petrology of Holocene fluvial sand derived from plutonic source rocks: implications to paleoclimatic interpretation. Journal of Sedimentary Petrology 46, 694-709.

Billingsley, G.H., 1987. Geology and geomorphology of the southwestern Moenkopi Plateau and southern Ward Terrace, Arizona. U.S. Geological Survey Bulletin 1672, 1-18.
Blatt, H., Middleton, G., Murray, R., 1972. Origin of Sedimentary Rocks. Prentice-Hall, Englewood Cliffs, NJ. 634 pp.

Bowler, J.M., Wyrwoll, K.-H., Lu, Y., 2001. Variations of the northwest Australian summer monsoon over the last 300,000 years: the paleohydrological record of the Gregory (Mulan) Lakes System. Quaternary International 83-85, 63-80.

Breed, C.S., Fryberger, S.C., Andrews, S., McCauley, C., Lennartz, F., Gebel, D., Horstman, K., 1979. Regional studies of sand seas using Landsat (ERTS) imagery. In: McKee, E.D. (Ed.), A Study of Global Sand Seas. U.S. Geological Survey Professional Paper 1052, pp. 305-397.

Breyer, J.A., Bart, H.A., 1978. The composition of fluvial sands in a temperate semiarid region. Journal of Sedimentary Petrology $48,1311-1320$.

Brooke, B., 2001. The distribution of carbonate eolianite. EarthScience Reviews 55, 135-164.

Cameron, K.L., Blatt, H., 1971. Durabilities of sand size schist and "volcanic" rock fragments during fluvial transport, Elk Creek, Black Hills, South Dakota. Journal of Sedimentary Petrology 41, 565-576.

Chen, X.Y., Bowler, J.M., Magee, J.W., 1991. Aeolian landscapes in central Australia: gypsiferous and quartz dune environments from Lake Amadeus. Sedimentology 38, 519-538.

Cooke, R.U., Warren, A., 1973. Geomorphology in Deserts. University of California Press, Berkeley. 374 pp.

Conant, L.C., Goudarzi, G.H., 1967. Stratigraphic and tectonic framework of Libya. American Association of Petroleum Geologists Bulletin 51, 719-730.

Coudé-Gaussen, G., Riser, J., Rognon, P., 1983. Tri éolien et évolution du matérial dunaire par vannage et fragmentation: l'erg In Koussamene (Nord-Mali). Comptes-Rendus des Seances de 1'Academie des Sciences, Serie II: Mecanique-Physique, Chimie Sciences de la Terre, Sciences de l'Univers 296, 291-296.

De Villiers, S., Compton, J.S., Lavelle, M., 2000. The strontium isotope systematics of the Orange River, southern Africa. South African Journal of Geology 103, 237-248.

Dutta, P.K., Zhou, Z., dos Santos, P.R., 1993. A theoretical study of mineralogical maturation of eolian sand. Geological Society of America Special Paper 284, 203-209.

Edgett, K.S., Lancaster, N., 1993. Volcaniclastic aeolian dunes: terrestrial examples and application to martian sands. Journal of Arid Environments 25, 271-297.

Franzinelli, E., Potter, P.E., 1983. Petrology, chemistry, and texture of modern river sands, Amazon River system. Journal of Geology $91,23-39$.

Fryberger, S.G., Dean, G., 1979. Dune forms and wind regime. In: McKee, E.D. (Ed.), A Study of Global Sand Seas. U.S. Geological Survey Professional Paper 1052, pp. 137-169.

Fryberger, S.G., Abdulkader, M.A.-S., Clisham, T.J., 1983. Eolian dune, interdune, sand sheet, and siliciclastic sabkha sediments of an offshore prograding sand sea, Dhahran area, Saudi Arabia. The American Association of Petroleum Geologists Bulletin 67, $280-312$.

Gable, D.J., 1980. The Boulder Creek batholith, Front Range, Colorado. U.S. Geological Survey Professional Paper 1101, $1-88$.

Gardner, R.A.M., 1983. Aeolianite. In: Goudie, A.S., Pye, K. 
(Eds.), Chemical Sediments and Geomorphology. Academic Press, London, pp. 265-300.

Geist, D.J., Frost, C.D., Kolker, A., Frost, B.R., 1989. A geochemical study of magmatism across a major terrane boundary: $\mathrm{Sr}$ and $\mathrm{Nd}$ isotopes in Proterozoic granitoids of the southern Laramie Range, Wyoming. Journal of Geology 97, 331-342.

Goudie, A.S., 1970. Notes on some major dune types in South Africa. South African Geographical Journal 52, 93-101.

Goudie, A.S., Watson, A., 1981. The shape of desert sand dune grains. Journal of Arid Environments 4, 185-190.

Goudie, A.S., Stokes, S., Livingstone, I., Bailiff, I.K., Allison, R.J., 1993. Post-depositional modification of the linear sand ridges of the West Kimberley area of north-west Australia. Geographical Journal 159, 306-317.

Greeley, R., Iversen, J.D., 1985. Wind as a geological process on Earth, Mars, Venus and Titan. Cambridge Univ. Press, Cambridge. 333 pp.

Hayes, J.R., 1962. Quartz and feldspar content in South Platte, Platte, and Missouri River sands. Journal of Sedimentary Petrology 32, 793-800.

Hea, J.P., 1971. Petrography of the Paleozoic-Mesozoic sandstones of the southern Sirte Basin, Libya. In: Gray, C. (Ed.), Symposium on the Geology of Libya. University of Libya, Tripoli, Libya, pp. 107-125.

Holliday, V.T., 1989. The Blackwater Draw Formation (Quaternary): a 1.4-plus m.y. record of eolian sedimentation and soil formation on the Southern High Plains. Geological Society of America Bulletin 101, 1598-1607.

Holliday, V.T., 1995. Stratigraphy and paleoenvironments of late Quaternary valley fills on the Southern High Plains. Geological Society of America Memoir 186, 1-136.

Houston, R.S., Marlatt, G., 1997. Proterozoic geology of the Granite Village area, Albany and Laramie Counties, Wyoming, compared with that of the Sierra Madre and Medicine Bow Mountains of southeastern Wyoming. U.S. Geological Survey Bulletin 2159, 1-25.

Johnsson, M.J., Stallard, R.F., Meade, R.H., 1988. First-cycle quartz arenites in the Orinoco River basin, Venezuela and Colombia. Journal of Geology 96, 263-277.

Kolm, K.E., 1974. ERTS MSS imagery applied to the mapping of sand dunes in Wyoming. In: Wilson, M. (Ed.), Applied Geology and Archaeology, the Holocene History of Wyoming. Geological Survey of Wyoming Report of Investigations, vol. 10 , pp. 34-39.

Kuenen, Ph.H., 1960. Experimental abrasion 4: Eolian action. Journal of Geology 68, 427-449.

Lancaster, N., 1989. The Namib Sand Sea: Dune Forms, Processes and Sediments. A.A. Balkema, Rotterdam. 180 pp.

Lancaster, N., 1995. Geomorphology of Desert Dunes. Routledge, London. 290 pp.

Lewis, A.D., 1936. Sand dunes of the Kalahari within the borders of the Union. South African Geographical Journal 19, 22-32.

Livingstone, I., 1987. Grain-size variation on a "complex" linear dune in the Namib Desert. Geological Society Special Publications 35, 281-291.

Livingstone, I., Warren, A., 1996. Aeolian Geomorphology: An Introduction. Addison Wesley Longman, Essex, England. 211 pp.
Lorenz, J., 1980. Late Jurassic-early Cretaceous sedimentation and tectonics of the Murzuq Basin, southwestern Libya. In: Salem, M.J., Busrewil, M.T. (Eds.), The Geology of Libya, vol. II. Academic Press, London, pp. 383-392.

Love, J.D., Christiansen, A.C., 1985. Geologic Map of Wyoming. U.S. Geological Survey map, scale 1:500,000.

Lugn, A.L., 1968. The origin of loesses and their relation to the Great Plains in North America. In: Schultz, C.B., Frye, J.C. (Eds.), Loess and Related Eolian Deposits of the World. University of Nebraska Press, Lincoln, pp. 139-182.

Machenberg, M.D., 1984. Geology of the Monahans Sandhills State Park, Texas: The University of Texas at Austin Bureau of Economic Geology. Guidebook 21, 1-39.

Marsland, P.S., Woodruff, J.G., 1937. A study of the effects of wind transportation on grains of several minerals. Journal of Sedimentary Petrology 7, 18-30.

McKee, E.D., 1966. Structures of dunes at White Sands National Monument, New Mexico (and a comparison with structures of dunes from other selected areas). Sedimentology 7, 1-69.

McKee, E.D., 1979. Ancient sandstones considered to be eolian. In: McKee, E.D. (Ed.), A Study of Global Sand Seas. U.S. Geological Survey Professional Paper 1052, 187-233.

McKee, E.D., 1982. Sedimentary structures in dunes of the Namib Desert, South West Africa. Geological Society of America Special Paper 188, 1-64.

McKee, E.D., 1983. Eolian sand bodies of the world. In: Brookfield, M.E., Ahlbrandt, T.S. (Eds.), Eolian Sediments and Processes. Developments in Sedimentology, vol. 38. Elsevier, Amsterdam, pp. $1-25$.

McKee, E.D., Tibbitts Jr., G.C., 1964. Primary structures of a seif dune and associated deposits in Libya. Journal of Sedimentary Petrology 34, 5-17.

McTainsh, G.H., 1989. Quaternary aeolian dust processes and sediments in the Australian region. Quaternary Science Reviews 8, 235-253.

Muhs, D.R., Holliday, V.T., 1995. Evidence for active dune sand on the Great Plains in the 19th century from accounts of early explorers. Quaternary Research 43, 198-208.

Muhs, D.R., Holliday, V.T., 2001. Origin of late Quaternary dunefields on the Southern High Plains of Texas and New Mexico. Geological Society of America Bulletin 113, 75-87.

Muhs, D.R., Zárate, M., 2001. Late Quaternary eolian records of the Americas and their paleoclimatic significance. In: Markgraf, V. (Ed.), Interhemispheric Climate Linkages. Academic Press, San Diego, pp. 183-216.

Muhs, D.R., Bush, C.A., Cowherd, S.D., Mahan, S., 1995. Geomorphic and geochemical evidence for the source of sand in the Algodones dunes, Colorado Desert, southeastern California. In: Tchakerian, V.P. (Ed.), Desert Aeolian Processes. Chapman \& Hall, London, pp. 37-74.

Muhs, D.R., Stafford Jr., T.W., Cowherd, S.D., Mahan, S.A., Kihl, R., Maat, P.B., Bush, C.A., Nehring, J., 1996. Origin of the late Quaternary dunefields of northeastern Colorado. Geomorphology $17,129-149$.

Muhs, D.R., Stafford Jr., T.W., Swinehart, J.B., Cowherd, S.D., Mahan, S.A., Bush, C.A., Madole, R.F., Maat, P.B., 1997a. Late 
Holocene eolian activity in the mineralogically mature Nebraska Sand Hills. Quaternary Research 48, 162-176.

Muhs, D.R., Stafford Jr., T.W., Been, J., Mahan, S., Burdett, J., Skipp, G., Rowland, Z.M., 1997b. Holocene eolian activity in the Minot dunefield, North Dakota. Canadian Journal of Earth Sciences 34, 1442-1459.

Muhs, D.R., Swinehart, J.B., Loope, D.B., Aleinikoff, J.N., Been, J., 1999. 200,000 years of climate change recorded in eolian sediments of the High Plains of eastern Colorado and western Nebraska. Geological Society of America Field Guide 1, 71-91.

Muhs, D.R., Swinehart, J.B., Loope, D.B., Been, J., Mahan, S.A., Bush, C.A., 2000. Geochemical evidence for an eolian sand dam across the North and South Platte Rivers in Nebraska. Quaternary Research 53, 214-222.

Muhs, D.R., Reynolds, R.L., Been, J., Skipp, G., 2003. Eolian sand transport pathways in the southwestern United States: importance of the Colorado River and local sources. Quaternary International 104, 3-18.

Nanson, G.C., Chen, X.Y., Price, D.M., 1995. Aeolian and fluvial evidence of changing climate and wind patterns during the past $100 \mathrm{ka}$ in the western Simpson Desert, Australia. Palaeogeography, Palaeoclimatology, Palaeoecology 113, 87-102.

Nesbitt, H.W., Young, G.M., 1996. Petrogenesis of sediments in the absence of chemical weathering: effects of abrasion and sorting on bulk composition and mineralogy. Sedimentology 43, 341-358.

Nesbitt, H.W., Young, G.M., McLennan, S.M., Keays, R.R., 1996. Effects of chemical weathering and sorting on the petrogenesis of siliciclastic sediments, with implications for provenance studies. Journal of Geology 104, 525-542.

Nesbitt, H.W., Fedo, C.M., Young, G.M., 1997. Quartz and feldspar stability, steady and non-steady-state weathering, and petrogenesis of siliciclastic sands and muds. Journal of Geology 105, $173-191$.

Pease, P., Tchakerian, V., 2003. Geochemistry of sediments from Quaternary sand ramps in the southeastern Mojave Desert, California. Quaternary International 104, 19-29.

Pell, S.D., Chivas, A.R., 1995. Surface features of sand grains from the Australian Continental Dunefield. Palaeogeography, Palaeoclimatology, Palaeoecology 113, 119-132.

Pell, S.D., Chivas, A.R., Williams, I.S., 1999. Great Victoria Desert: development and sand provenance. Australian Journal of Earth Sciences 46, 289-299.

Pell, S.D., Chivas, A.R., Williams, I.S., 2000. The Simpson, Strzelecki and Tirari Deserts: development and sand provenance. Sedimentary Geology 130, 107-130.

Pettijohn, F.J., Potter, P.E., Siever, R., 1972. Sand and Sandstone. Springer-Verlag, New York. 618 pp.

Pittman, E.E., 1969. Destruction of plagioclase twins by stream transport. Journal of Sedimentary Petrology 39, 1432-1437.

Potter, P.E., 1978. Petrology and chemistry of modern big river sands. Journal of Geology 86, 423-449.
Potter, P.E., 1994. Modern sands of South America: composition, provenance and global significance. Geolische Rundschau 83, $212-232$.

Potter, P.E., Huh, Y., Edmond, J.M., 2001. Deep-freeze petrology of Lena River sand, Siberia. Geology 29, 999-1002.

Pye, K., Tsoar, H., 1990. Aeolian Sand and Sand Dunes. Unwin Hyman, London. 396 pp.

Schwab, F.L., 1975. Framework mineralogy and chemical composition of continental margin-type sandstone. Geology 3, 487-490.

Sims, P.K., Gable, D.J., 1967. Petrology and structure of Precambrian rocks Centeral City quadrangle Colorado. U.S. Geological Survey Professional Paper 554-E, 1-56.

Suttner, L.J., Dutta, P.K., 1986. Alluvial sandstone composition and paleoclimate: I. Framework mineralogy. Journal of Sedimentary Petrology 56, 329-345.

Suttner, L.J., Basu, A., Mack, G.H., 1981. Climate and the origin of quartz arenites. Journal of Sedimentary Petrology 51, $1235-1246$.

Swinehart, J.B., 1990. Wind-blown deposits. In: Bleed, A., Flowerday, C. (Eds.), An Atlas of the Sand Hills. University of Nebraska, Lincoln, pp. 43-56.

Thorp, J., Smith, H.T.U., 1952. Pleistocene eolian deposits of the United States, Alaska, and parts of Canada. National Research Council Committee for the Study of Eolian Deposits, Geological Society of America, scale 1:2,500,000.

Towner, R.R., Gibson, D.L., 1983. Geology of the onshore Canning Basin, Western Australia. Bureau of Mineral Resources. Geology and Geophysics Bulletin 215, 1-51.

Van de Kamp, P.C., Leake, B.E., 1994. Petrology, geochemistry, provenance and alteration of Pennsylvanian-Permian arkose, Colorado and Utah. Geological Society of America Bulletin 106, $1571-1582$.

Walker, T.R., 1979. Red color in dune sand. U.S. Geological Survey Professional Paper 1052, 61-81.

Wasson, R.J., 1983. Dune sediment types, sand colour, sediment provenance and hydrology in the Strzelecki-Simpson dunefield, Australia. In: Brookfield, M.E., Ahlbrandt, T.S. (Eds.), Eolian Sediments and Processes. Developments in Sedimentology, vol. 38. Elsevier, Amsterdam, pp. 165-195.

Wasson, R.J., 1986. Geomorphology and Quaternary history of the Australian continental dunefields. Geographical Review of Japan 59, 55-67.

Winspear, N.R., Pye, K., 1995. Sand supply to the Algodones dunefield, south-eastern California, USA. Sedimentology 42, $875-891$.

Wopfner, H., Twidale, C.R., 2001. Australian desert dunes: wind rift or depositional origin? Australian Journal of Earth Sciences $48,239-244$.

Zimbelman, J.R., Williams, S.H., 2002. Geochemical indicators of separate sources for eolian sands in the eastern Mojave Desert, California, and western Arizona. Geological Society of America Bulletin 114, 490-496. 